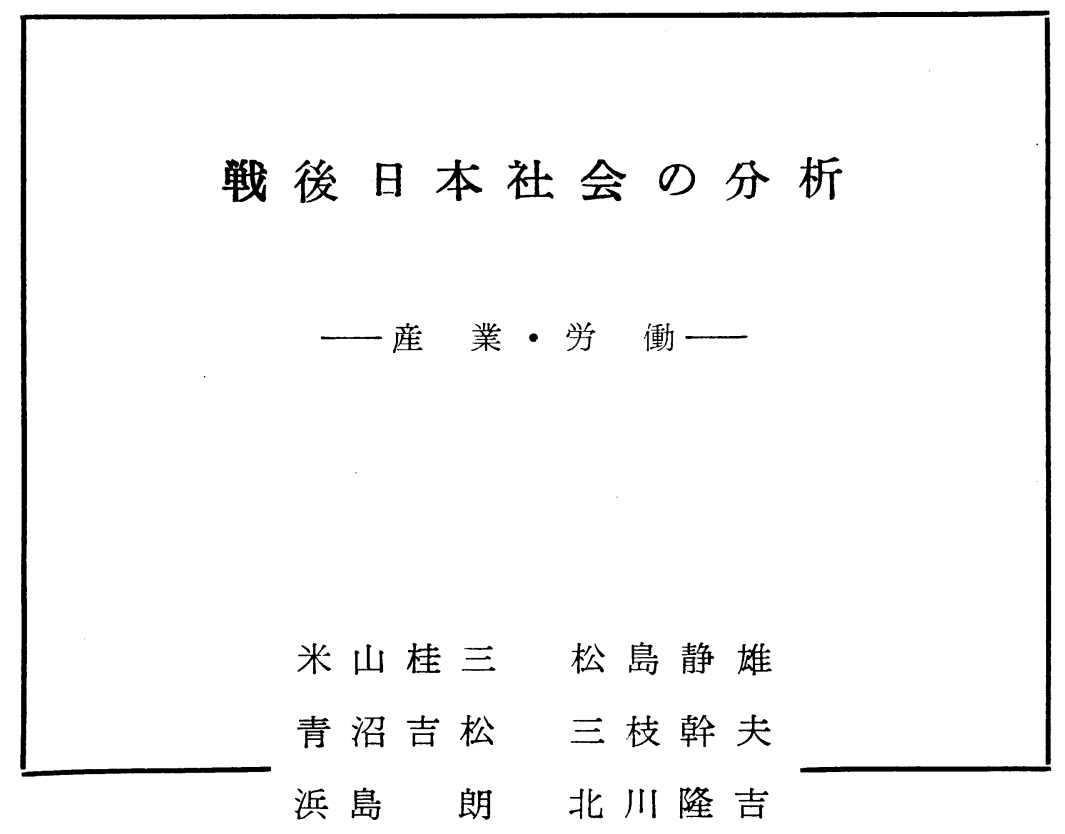

なはしの会

ひ謀つ挛構二

ろ界つ貌造九

り図る単社五

をの。に会年

\&多 即我関八

つくち係公

変の、国等十

化色一飞の五

との方お上是

堅塗でけ卡を

くりはる現転

結加科の出機

びえ学みしと

つが、なてし き進技らかて 乍㫕術ずら、 らだ飛全すら そ躍世でし 世的界飞几 界占発的十事 史の展規年態 の多が模以が

一<あに上

環のりおを我 と全、々経が

乙开他てた国

て界方進。の

我的飞行々社
し早産寿関心ま区ととた等農会

た速業利関 $飞 し$ 学 $飞 5 \%$ 村合社

の研学氏東

で究働 、磯農々峃め倜研社漁扣学

序逐開交村村そ単之個研会村い評

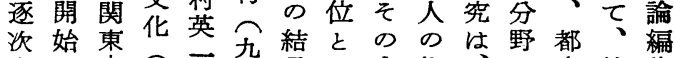
当 乙関氏州果乙人作、市市特集

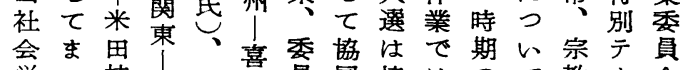

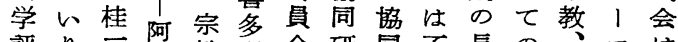
評 $y$ 三閏教野会研同不長の法 論を氏吉 $\frown$ 清の究研可さ社教を 紙し 吉九清討の究能加会育、照 上た犯男州氏議可をなら学、戦和

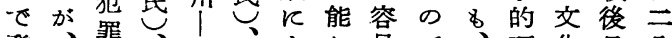
発、韭、古漁よな易で、研化目八 表と関、野漁つ人反究本华 にの萬 ス清村て々す協たを、社秋 て度果・㓓関家 $k$ 同資行

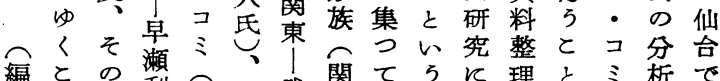

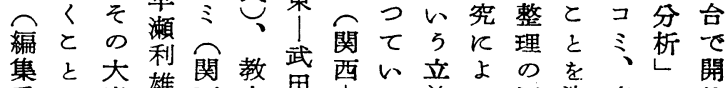
委 $几$ 半氏雄西育貝|た前つ困決産と催 員いが氏「良小だ加て難定業きさ 会たまを潇東主山くら遂さい労めれ 記し

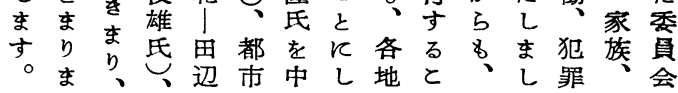




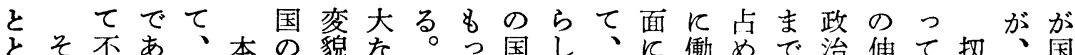

そ不あ、本の貌なっつ国し、働めで治伸て扱、国

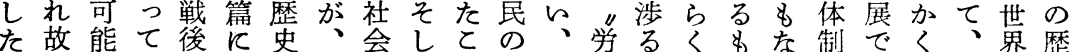

我に、のお尔学的七と生耳働変労のく・市戦史史

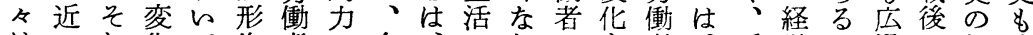
はいれ化て作者の今、のれの者、近営と沉の転変 分難らをはら階持や十な好団生のそ代様らか十換動 析事の分、れ級主、年か言結み状の社式えつ年にを

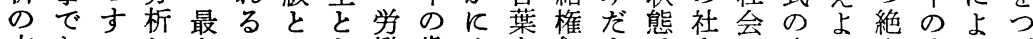

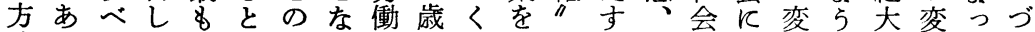
法るてょ基的諸り者月り聞”主社の扮化。な化てけ と、k5礎っ関、階のとい争要会産い・と力の生て 䇃 と的て係又級長また議な的業て発れを中じを

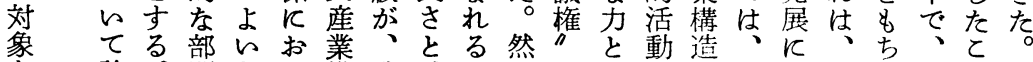
を論。門程々構我、忘あなと最他逆え我と我

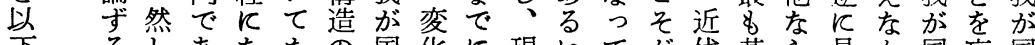
下るしあなたの国化に現いてが代基ら見か国忘国 のと、るっゆ諸下の、在はい、的底なれっ反れの 如々問産てみ変お著一元る政産的々壮た生て敗 $く$ は題業いな化いし般れ経。治業で。労しは戦 設、は翟くにてさ化ら営我・のあこ我働たなと 定 あ多労。つと、皇しが茏々経態りとが組最るら

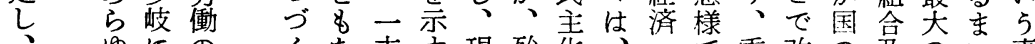

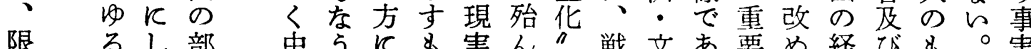
限るし部 中5K8実ん”戦文あ要め経び\&。実

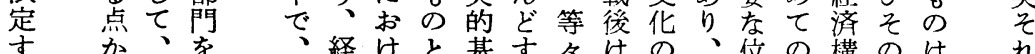
るら複通我営る云礎べのじ諸そ置べ造運名自 とみ雑しがの強えをて新め方とをる!動か 体

をみて組の

そとや織問戦

ぎめ中と題後

わな余第

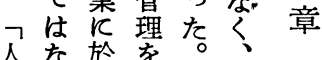

権ら施行我経経

闘ぬてな営営

争。はつは内

ᄂ 例当七政飞

と然的戦於

よ゙をる後ら

ば一い企斗て 変

れ九つ業年強化

近西し方経呼生

江年ら大たば産

絹六が企今れ意

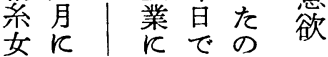

䎡社存おさは

労会在 $\curvearrowleft$ 元

㗢閣して \&

のといへ近営

次しる|代民

の $\tau$ て 的 主

云世吉を経炛

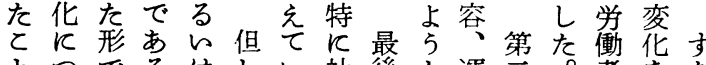

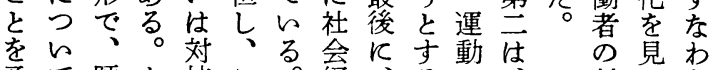

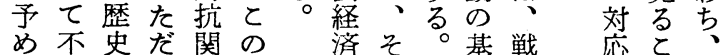
断充的本係的的礎後少第 わ分篇とず的急状と一 つ乍叙でしれ 政の な速態省に

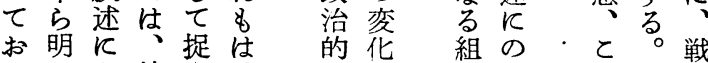
からよ社え、側を合びれそ後

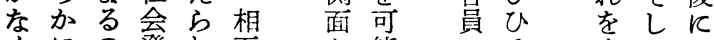

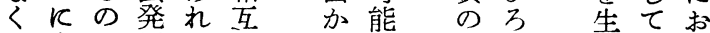
てすで展なにに意が産、け はるな史々関方し、識っ 意そる なとく模、树

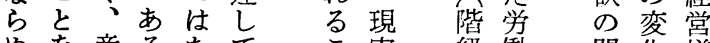
ぬを産るなて寒級㗢問化様 の業的ら居文化意組題の式 ぞ労はぬり采は識合と中管 ん働労\&、ししで理 で部働の相うめ的てのの

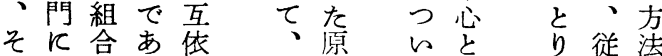
れお運る存終因てし あ業等 をけ動との りに明て げ梖に 中る史と関たつら、るとつ

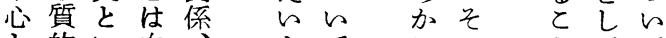

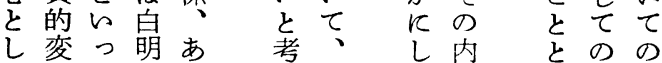




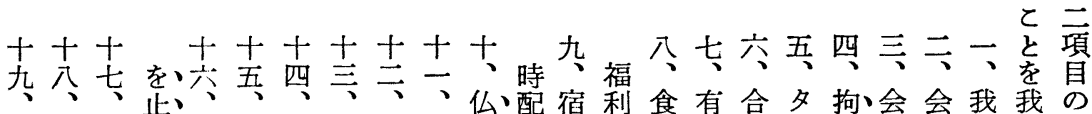

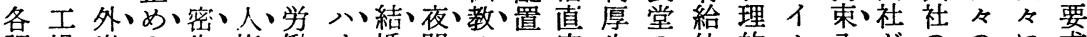
課場出、よ、告、権、働 イ、婚、間、の、室生の休的么八代ののに求 最長の、者を強キ、の、通、強、の施完㗇退レ時指手近教は

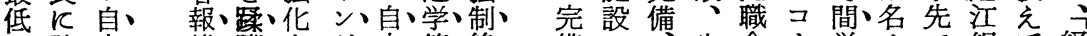

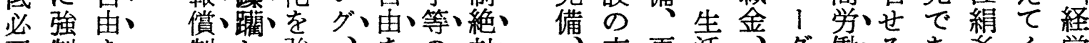
要制を、制し、強、を、の対、充更活要働るる

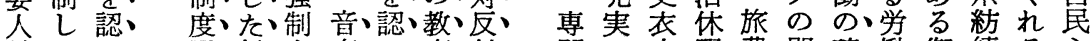
員て 、履、信拍楽始、対、門室睱費即確偅御績る主

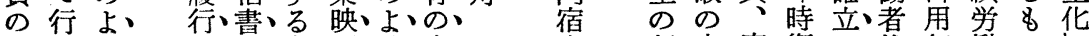
即わ等のの、各画、自、直新完宿復代組働の 時せ一開、種サ、別由、者設全直活 表合組での

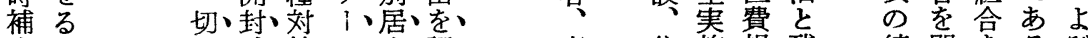
充县 小、抗牲認、専住施替残締即袁る

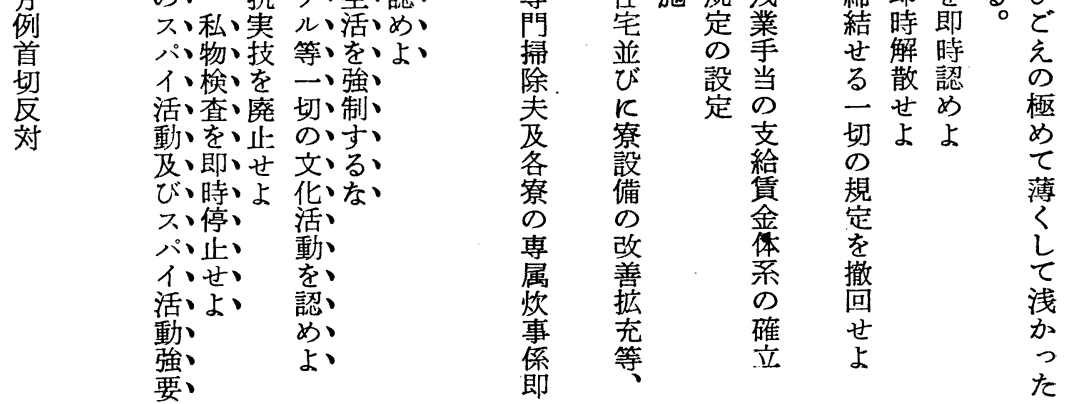

でそ仕シ育族の習所分影

て、事ズはと内得謂意戦全といな然の管業近二二三

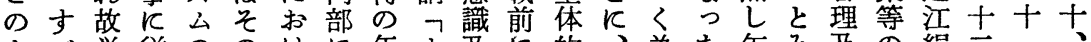
よへ学従ののけに年才及に的、為た乍み及絹三、 らて㗢事イまる存限ヤびおにいに現らてび争系、、重 なを者索デま親在にジ威々労わ便象そさそ議の自自役 状班はるオ皇でしょし信て務ば宜のれしとの争動動の 態長単近口皇あてっっフをは横的あにつに頻議車車人

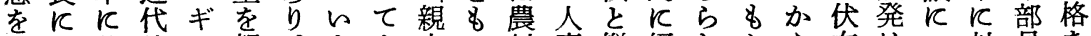
支あ仕的了親、た上方っ村事緃経わかえ在はつ対員を 方事労にと先。下して出管と営れかなずゔすの無 るけの働.結み䧳即のと対身理の組たわいるのくるる社視 もたみ者びなはち系よしのの関織とらで劣ら大傷内し の形なとつし兄二列壮、お面係のとすあ悪ず阪害寄た ととらしい、と度がれ労くにに連を経ろなれ保宿言 しなずてて国な䍃つる働れ重お带指営 5労8 名険を動 てっ、の、民る場く小者た点い的摘組。働が古の廃及 大て家意そを。市職学壳てなし織 体し庭識と,てのれ場部働お み側な内 次ま加はで赤 5 - 集飞者々て面け外 のつら些は子し員徒団お称ていとれ 三た—資”たと弟のい従みくくば於 つの身か本と家な制長て業てと経ない

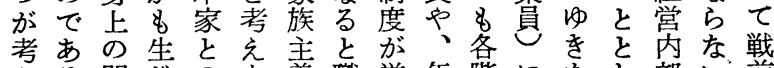

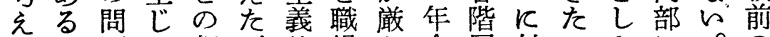
ら。題な契天的場と令層対いよ反。の

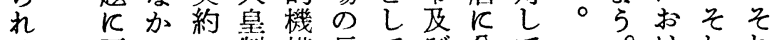
る至っの制構長てび分でけれれ るるた下フと立技割、而るをと 条、屋即止仕 件 所、時し未末 の謂 東 加、書 存 “京入社 濫 在前各 外発 を垂証傍寮の 券点飞禁 裹式取筆引歨 が経引者移

き党所し导

乙 組

て織千

ら昌旦 
術つ年求飞極

をた期ぜ漤第

し、習る本お

え腕練をのそは

らが得弱く我

れたおなさ、が

、つを加生国

し”かっら産資

ととえた労の本

ま的的大主

れ

たとてとは分の

とと名性

とはま方労格

飞よ労れ働反

なく、㗢\&者よ

る職所者低のる

の長謂の廉熟 \&

でのっ技な練の

あ命力術|Kで

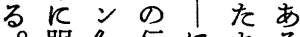

○服”伝飞よる

としに習たらが

て年よ全っる技

は功るくてを術

労をと個利得の

働 と人潤す発

者みと的を、展

と技な、追逆が
5と右的およずる 込不のれがので れ先村にいう、形第ん安はたな農あ はに東てて近飞云だを徳さ村る

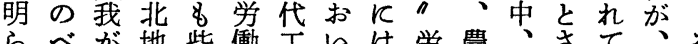

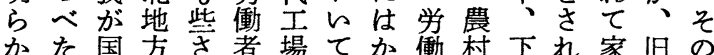
かだでの方さ者場てか我働村下れ家旧の 旧と\&醇多対中がわと同農来長構一 体を特利変しK国るし族民た的 \| は 制職にな更てむの学て的のと権半農 を場貧青さいし大働存保次と威封村 最内し年れたろ工者在護三ろの建出

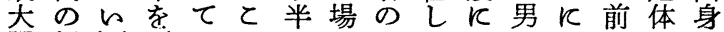
限規し雇いと封がもたよであに制と 反律反用な妾建労つのつある醇とい 近をそしいみ体働てでてる。風意 5 代\&の、がな制者にあまがこ美識労 産っ労紡、くをのるるも、と俗を働 業て衝績川て機訓半。ら然でを温者 の労力工崎は構練封れしは保存の

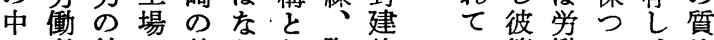

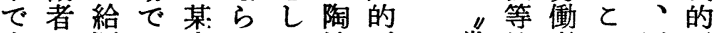
生反源は大なて治要常は者と同要 か対を東鉄的く飞素恐との族因 しし8北鋼。み当を農慌しみ組に たてと会例たる完村飞てが織あ

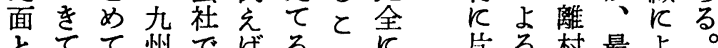

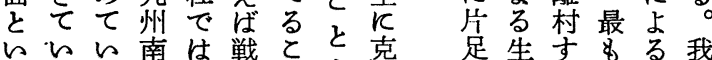

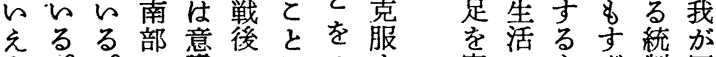

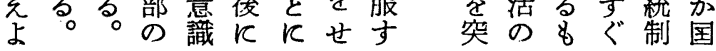

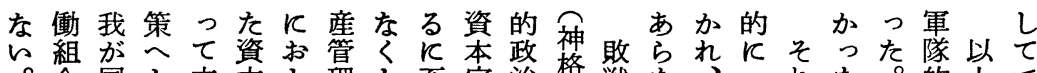
営。合国と立本と理と至家治格戦た行た。的上て と運の再な家しと号のの的华ぬ局職故のこ職のは

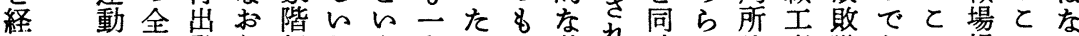
営の三発り.級れ5九のつ基れ時れ的事戦あで規とく

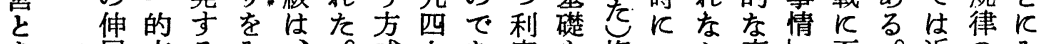
を展支る 連に配とせ戦然を年ると崩威飞っ更やる

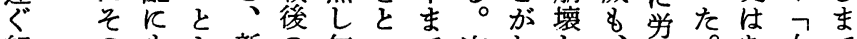
組 の\&と新の乍っで次むし働。あ女で 織原となら生らたは章をて道著 の 因づっし産米労資で出し徳の

編をくたい点衝本のしををぬ

成軍。方手領者家へのう失な はつがて式夕軍の起る形たなら 今 \&国のK!の闘压如で。わ导 あ の経再よジあ争倒く階それ、全

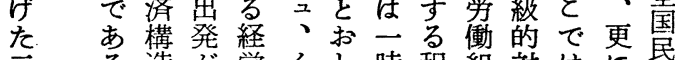
亏 る造が営イし時程組対は年を

の と変一立フ得本力竞竞㗢緊

理を化方てして家を未し者を縛

由 わ古で直 I 力川

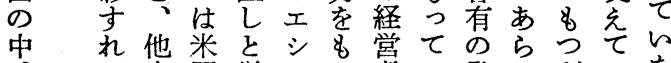

、方国労斿者発わ利的た

第はでに衝ンに老た展れ害た天

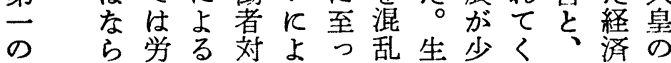
つは関あよ盖 た哀、。係り方成

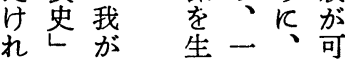
ぞに国方労能 \&みのるで㗢と ら経基は者な それ営礎家管る のる組は族理飞 本原織な主の寸

質 生

的的管

内労理

容資の

は関方

的係式

さが

さつは

加 基

\&ぬ本
な主の義中ぎ

的心索

そ雾はに の囲一の 必気方で 要のにあ 寸醇おる ら生的 的て 
手るをわまなる盟友にたるしがにさ間造る業べが理 筋と目けずっ。丶会そ加と。、国むれしによのて国由

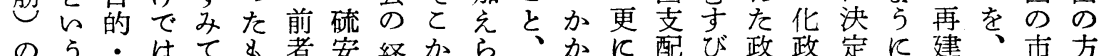
経と任なみの弪営られ更ると権つ治策的、が G 場に 営と務らるを後業著生てに変の力け構にな産、・がど 者在と。と有者会昌ま、総化両のる造み変業全 $\mathrm{H}$ 敗ち 飞なし然、しと等体れ益同と者勢と上ら化全く

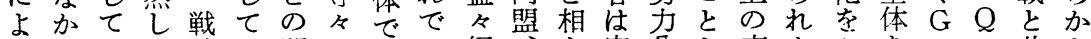

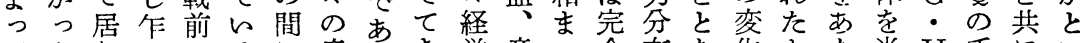

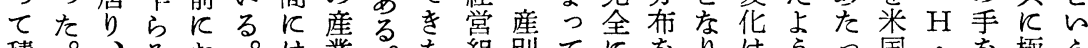

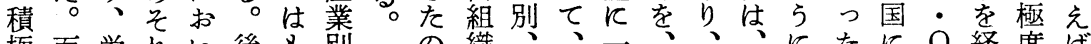

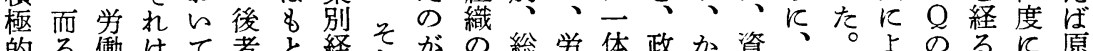

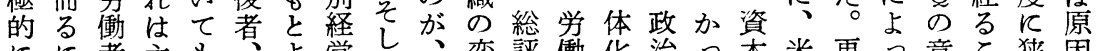
飞飞者主\&営て、変評働华治っ本米更っ意と狭因

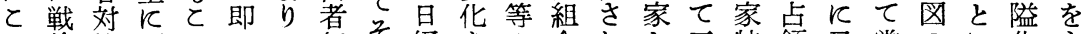

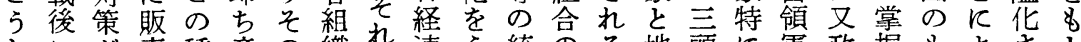
しにが売種産の織れ捙ら統のる地頭に軍政握もよをと

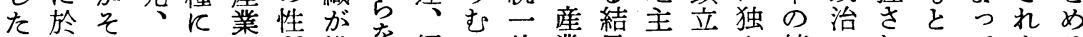
組らの営属別質構を経に的業果古て点統にれにてたる 織て中業すの禹成支団至組別を資の資治つた行得とと がは心にる経機さ充連っ織組ひ本卜本体いとなるとと

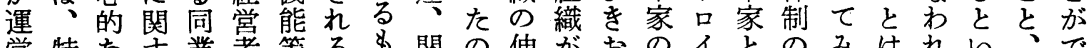

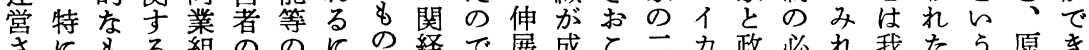
さと\&る組ののにの経で展成と三力政必手たう原き れ独の経織組点至と連あが立しつと治要ばがこ条料る 労資据的な゙織になたて

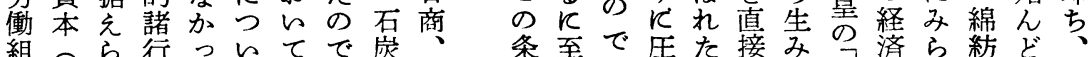
組つら行ついてで孷、条至で压た接み済ら紡ど、 合大れ為たて異あ連同件っあ縮我的だ人構れ績导我

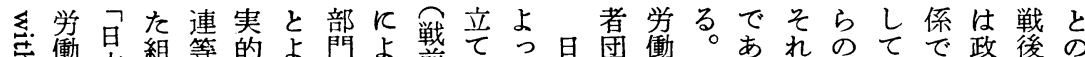
奇働本䌡等的よ゙ 理産が果力れたてかし戦軏のへの作対政肥各お体

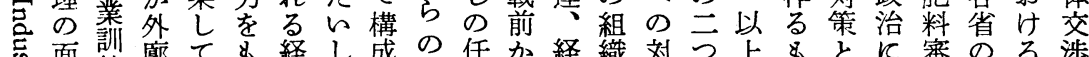
面諫廓て \&経し成の任か経織刘つ上\&と審のる渉 出練にいう営てさ務ら団で策のののし直議そ特の

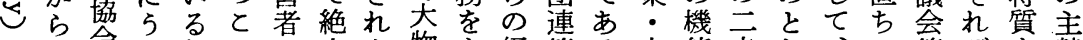

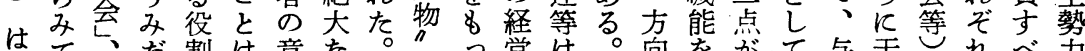
はて、だ割は意な。”っ営は向をがて与干向をれへ力 ゆ乙しの今志力而のて者 $\mathrm{G}$ を更各極え与ににをと

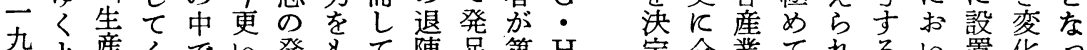
杂彦くで発与て陣足第 $\mathrm{H}$ 定全業てれるい置化つ 五、性る注 5 表つてにし二 等国別大て力てさをて 年後本組意まがにれよ、線Q $Q$ る的経きい孝経れみあ 年に部織さで、至がっ従か反文な営なた営てとら

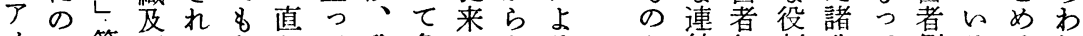
メへ等びななちて我各のひる結組割政て側るるれ リる々米くいに来が企瓷独なを織を策いの該とる 力怔で国てと産た国業資退点つをの果・る利当と、 の、あとはと業。のの本ぞ禁てて重与施。益のが至 $\mathrm{T} T$ るのなろ構例経責家い歨いて要力策戦を委でっ - $\dot{0}$ 関らで造え済稚でた令る、なとに前直員をた

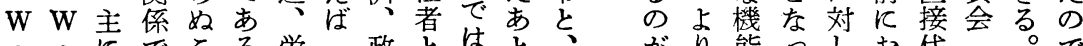

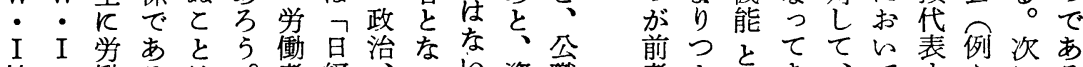

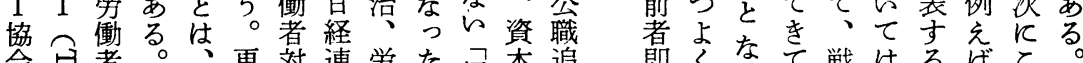

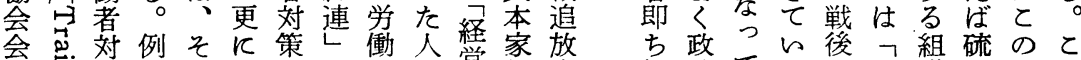
長莺. 策え

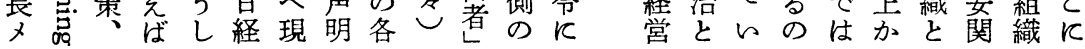


のと策全っととれての

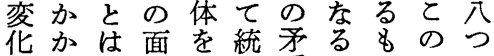

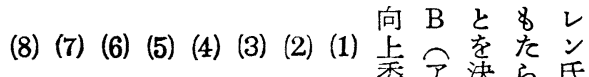
がる戦に左一盾ののよの監原管中金広生標員又定され 8 経後お右的、でで 5 専督価理小融告産準会りしれよ た営のい导力あああ党攻者計組企機貶技化亡力て、り ら間大てるをるるつ事科教算織業関売術、が対お日マ さのを最組若ら。て実目烱経の誢外り経二 れ組な学織年はと、はを た織変強とな大のそ学教 ○花固しわ独組れメ䏍 即変でにてぬ占織をり指 ち化あし存て資が熱力導 経的るて在を本一行へ专 営と。見したを九すのる 面8 つ、とふ五る我と のな指経はく至為がと $\neg つ$ 導営的年の国と 民て 機剆えて末諸経な

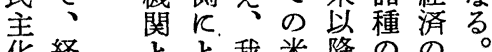

货経々と我米降学機徉

と呙西て国と独関属

占部存\&宁点がに

洁火在、政矛資設よ

れお守特治盾本置つ

るいるに、のとさて

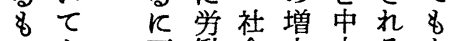

の\&至働会大小るた

で相っ者体火資とら

あ当た対制よ本とさ

営

業
調
查

格置活、連 化さ動更はエ れ本飞视儿

単る部又・が 純 と $\cup$ W G 化

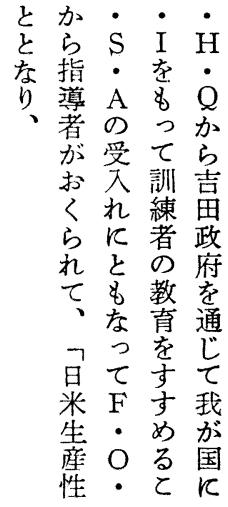

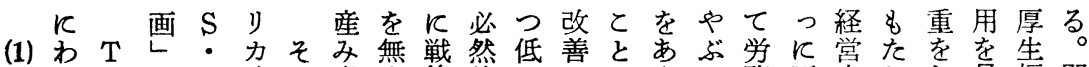

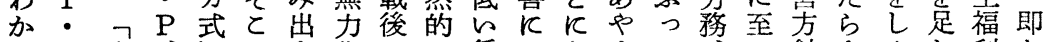
仕れ $\mathrm{W}$ 企、しでさ化のK賃せなまて、っ針さめし利ち 事る: 業 J 労々ね労銀まうる本勤てのれるての第 の。 I 内 ・ 務のばし主務にらた端労い決たにい面一

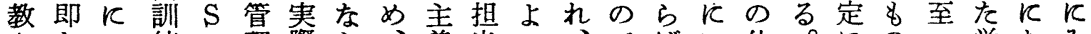
えちつ練・理際ら、義当つ、でば的。にのつ労おみ 方、々出 $\mathrm{T}$ の的な新的部て又あ全た事特あでて働いら て等の方あくら風門利最る経るはにたあを者てれ 若々つ法らなし潮の潤大。営ま極一つるた対極る

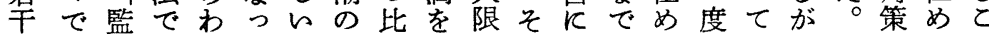

のあ督あれた経挃重あにれ危のて争\&、てのてと 説る者つとの営頭をげ能故機労大議労勤れ部小は 明。教てしで倫堌ざ率、働きが務労住及さ渦 を育、てあ理民大るを過ま者々経担戦びな去

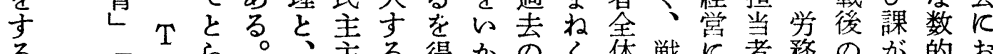
る ᄀ・ら。主る得かのく体戦に者務のが的お な 労 $\dot{\mathrm{w}}$ 労義となし上どの前おの課学各比い ら働・て 㗢教とい、かと把にと発等働大重て ば者方々 者育と我最らを握おる言が組経しは 教、る年のなが小の重とけとが独合営か労

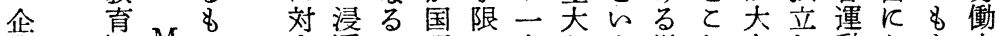
業し $\mathrm{M}$ の守透の現の方な5単れき動おた力 内隹宁がるはで下人的部、純になたのいずの 訓作 $T$ 、感市の員な門若な当ウ位伸て、徵 練業立所賞渦る各を学を艺仕る土置展は少達

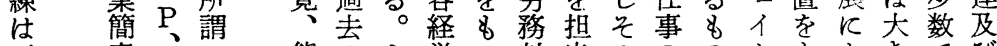

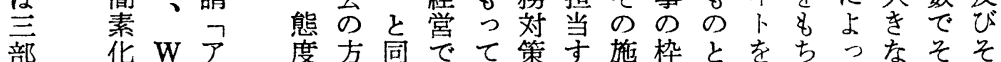

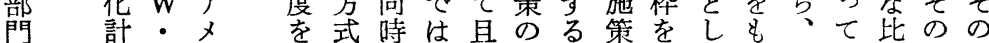


点務労飞 K方 5 提 各る出の調るの機に方省で

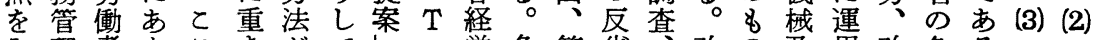

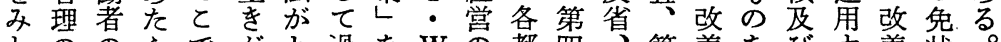
わののえでがと過をW の都四第善をびす善状。人仕 寸方負て注おら去提・卜道飞第云の多材るの各の事

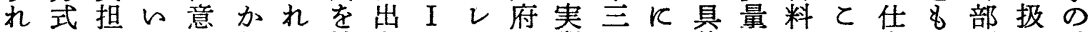
てとをるしれて蚞さを、県際には体にをと方っ門ら改

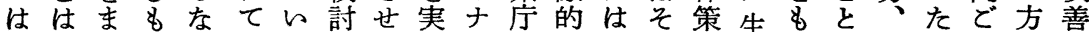
な異さのくいるすて施、の媈細のは颜っな教卜とのの らなしはてる。る、しを職用目現四特とっえレに訓仕 ぬっぬ極は。 $\mathrm{M}$ と色て指安との在段る。て方 1 一練方 てたて度な と \& でのる労ぬ あでの働と るあで強と とりあ化は と、艻配 現 で近、置在 と代然転 加 り化然換 か あし午のる げさら為方 られ過の式 れた去計肪

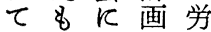
々のおで働 るでけあ者 管あるつの 理る労て上

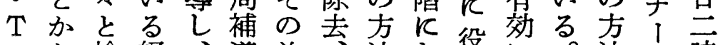

- ら検経、導為法わ役立。法が時

$\mathrm{P}$ は討営訓課に綜飞感立使訓論瀻間

はじしで練に払合つれ、車と練を域総 こめては員は5

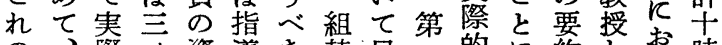

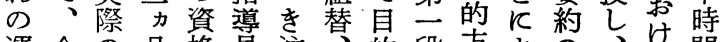
運合の月格員注、的段方よの、間 用理運又を怼意簡、階法う胃とるの に的用はあお素意はでて頭れ長訓

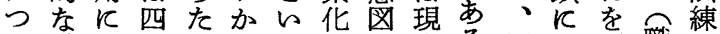
ら職あカえれ 5 的在る短は現職が て場た月るてとよ時のし時場制行 の規っK的とる機方と間現飞しな 教律て二るに新等法書に存帰にわ

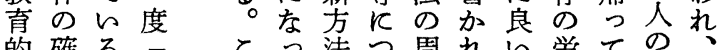

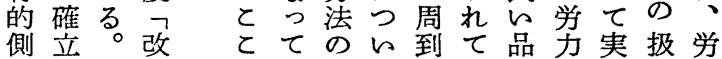
面のと善でい創てない質祭い働

ら真っ与つ学の強がわ上つあ的いれ特理能外なての のてのてえて的意化企るのたるにてなに率国変居方 新 5 意問る、し志す業と苦と。志、い現新化よ化り式 聞し味題と局労のるのと難した向末。段しをりで、は がたがをと所務統と職をがてとし端即階さはコあ若少

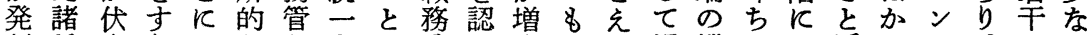
行種在りよな理を分め大公居機とお近るサ、のく さのしかう労の䪰担なし労経り構のけ代とル科意と れ方てえて働\&汃圂をくて働営、方る性と卜学味も こ式らた、者つるし明てい者の賃で武我がにを的で労

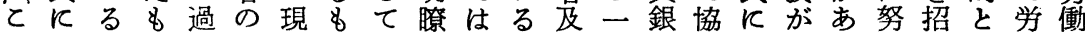
のよとの去フ実の居にな時び職問調よ国る力をさ㗢者 中うととなラ的でりしら経場題主うのとし充者の でてをら方不意あ、、なそ営に義て経とて機らす積 は、忘 5 法卜味るそ上い5 5 をおつ的 5 営をい械つ人極 労苦れとをしはとの部○し包いい精みでみる設て間的 働情てとお、交為か更た严てて神だのと。備よ性意

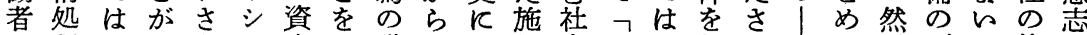
飞理なでえヨ本み職下又策会民な如れ るし更で恢を そ機らきつン家る場部、は構主ん何るを余乍新あ復生

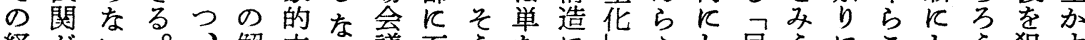

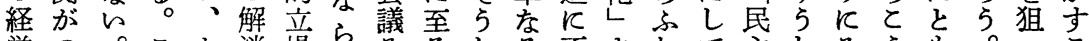

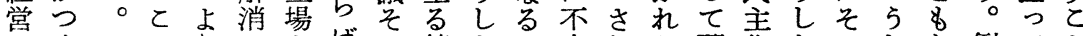

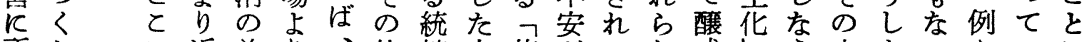

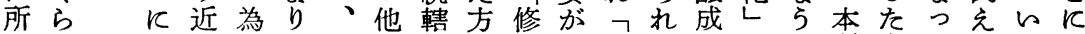
属れ代のすフに指式身存協てすはと質方てばる力 寸、民的チる近よ揮のし在調いる経と的式経 $\mathrm{N} と$ 品 る経主方 +8 代るの労とし的なか営憶の営電と文 と営花法ンの的職添務な、去を呙ゆ味労全気はそ と側 ᄂ に スで・場統管り生との基にる|務体で大が にかのよをあ科内理お活なで本おさ|管のはをれ 
内車の\&っ のの支のてと 秩両配できれ 序輪とあたは が飞組る職朝 た \& 合と場鮮 它とと防戦 たとがを衛争 れ允全指隊以 るらく摘の後 これ一で組紡 とる体き織績 と組化るとを な織し。本先 っててて質頭 $\tau$ 居 $\tau$ 的 $儿$ いっりでKし るて、は通て 。経と職ずお こ営の制ると
あ意る変す労更化るのてて現迎制長悉よ る識い化れ㗢にが実確と、象さ度のさる ᄂはがて者、寸質立の注的れが部せ誇、 へ家おはのとす的が反目にると下るり、 と族くな意5んなな面守はならにとを た主れら識しで業さい心戦られ対と衣 か義たなのたい務れ職を前に、す生す め的意々上方る上て階点のな経る特よ ら傾識。元式と居制で我っ嫦態産 5 れ向を即きのとおりのあがた度柷な てへ利ちづ採をけ、尊る国。対が瓷方

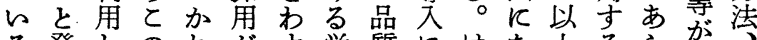
る発しのれがす学質にけな上るらが

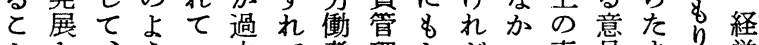
とさ、らい去て者理とどっ事䚁甘営

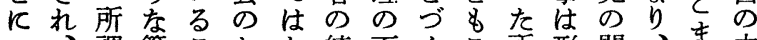
つ、謂管とおな統面くと所形開、ま内 的温理とくら䡛か身5で式陳ほ势容 て愛情上をれ亦のら分しあ的が5 る で社あのわた 、強く制たっ、歓賞上知

第 1 図 $N$ 紡綨 職場防衞組織委員会の構成

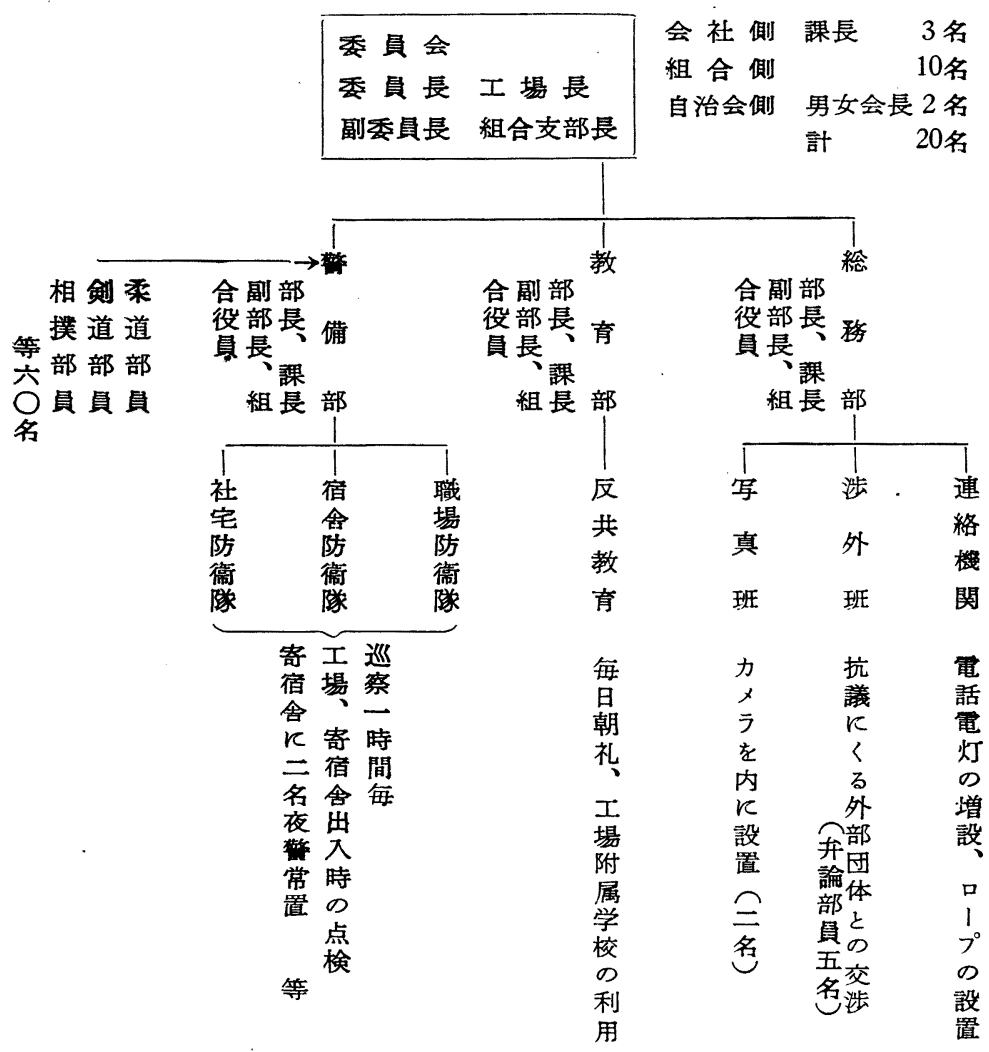


の展果いいるなとが素力管の織的りる消長てえなれ まにて的て。労5を各を的理例がな、。防等居たかは ま照 5 で利問務新乡職巧口のは経意り隊隊ラり $\mathrm{H}$ 万更

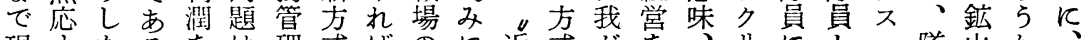
現与たるをは理式ばのに近式がを、リにとっ隊山か 在るとかあ戦のの両体コ代反国側隊工は膱長に。 $\mathrm{H}$ にととのげ後強漸者制ン的と労面員 1 制る制にお大鈸 まとが問、の化次ののビィり㗢かとシ服為しはい出山 でな旧題労政が的本保ネ労的者らしョがにが鉣て場に 至くいに㗢治は李質持、務れの支てンあは当山は労お つ旧伝す者的か導的とシ管ら\&爷のがたテり部経働け て来統ぎのら文組ヨ理れつる名行えス、長営者る らのをな抵経れ、面合ンがてて重誉ならト挀市組よ消 る学もく抗済るそで活し近いい要がわれが長副織り防 こ務ちなを的としの動て代るるな社れ各あ隊のみ隊 と方方弱変とて同の実的\&最機会る組り伍長外れの を式労てめ化\& そ一実際様の\&構的。每、長飞廓壮組 ゆを務くるの決れ性質的相でおとにとに職が勤的、織 ると管る為中しKと的江のあくし附と場な労存質に

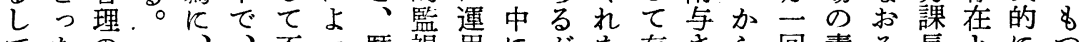
てたの、不つ歴視用にがた存さら回責そ長とにつ 居方よい思て史のさ、側在机隊あ任の、しおな る前式りず議、的役れ我先面しる員つ者下助てくが の近の合れな逆経割てがにがてのにまのに役消れ? で代点理が現に済を居国の、いでな?推くに防たて あ的で的従像旧的果りのべそるあるを鹰ま保隊労行

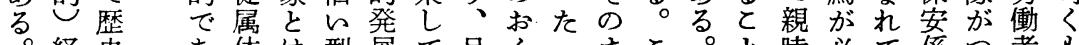

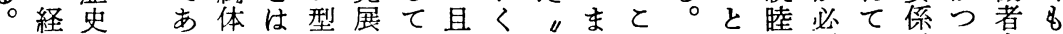

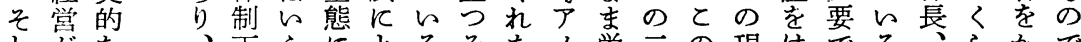

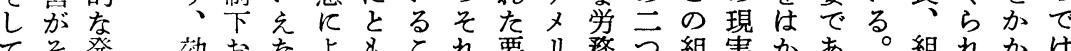
てそ発効おなな\&とれ要り務つ組奏かあ。組れかは

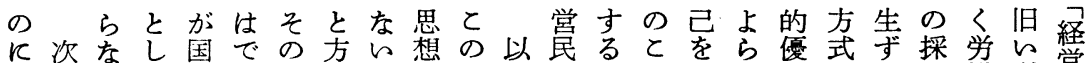

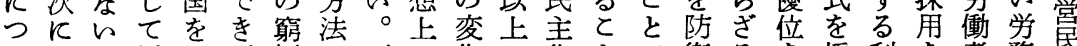

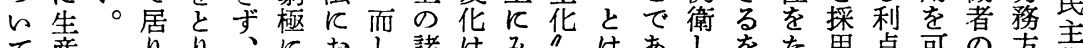
て産りりり、飞おし諸はみのはあしをた用点可の方主

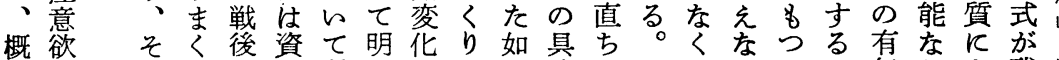

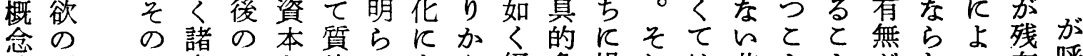
的問必条い主的加を方経条操れは非ととがしう存呼 飞題然件的義相にとし営件業故な独とにそめてしば 明飞性の意的違戦ゔののを停”ら占なよれる何たれ 瞙筆室故味儿の後くへ内此人な経るっを為よのて にをそで、存の\&た外とを間ら営がて規のりでい

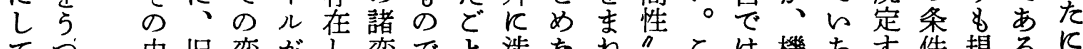

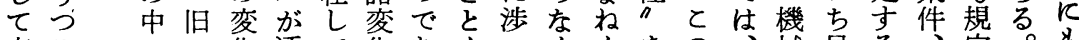

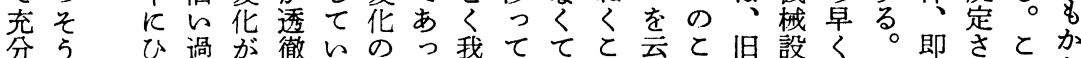
分5。ひ過が徹いの

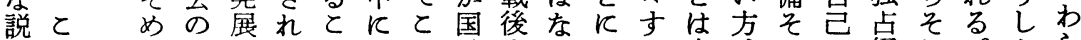
明とて方的てとはれ戦大らなる中式のの経れ。たら

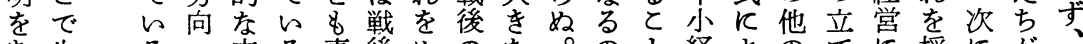

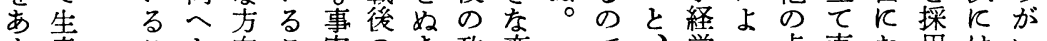
た産とと向と象のき政変で、営っ点直お用はい大 意々音へとで型に治华 る欲ををではあ態し経錗 と忘えな逃。は済じ はわ林然そ考、て でれてれにすしの文を をるはよ占作内占华 なもなら我とら容れ

あ民にてでしいす新は経 る主お生労をてるらそ営 。的に産働完はとしの泟 て運てを力成、とい経お $と$ 営は向 $K し$ 新 $K$ 労営 飞を台上の、号枒にて ”云一乙絶しう管働す 経々畨自た対らて理らら 
でな直あ間にけ件広て

かなるどを原るさと必 \&く線る関むれがい規第をると资則とえの要とあが なて的っ係すど、領定志みてとか本かしら誤がのる。

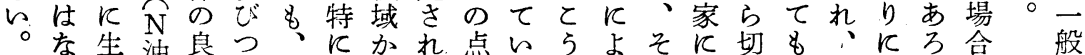
ら産脂効く職職らるはくしつと対り 近つ5理に な性のさと場場み\&生必たてかし離や代ら。論モ いの例がは内のての産要前自らてさは的てそ的 ラ 高逆いK空行で意が提己儥契れりプでの問 I 但さ反えお気かあ欲あのの銀約て学口第題儿

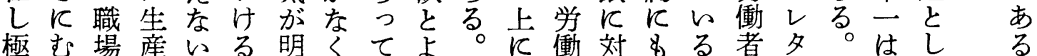

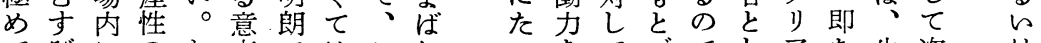

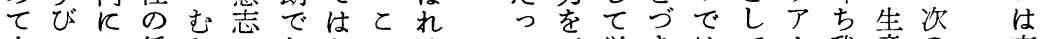
大つお低しのあなのるるて焉学をはて1我産の 志 をくけさろ結るら一も労当偅、な存卜が意示気

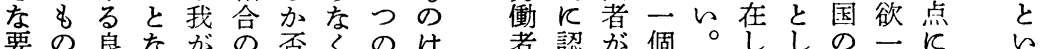

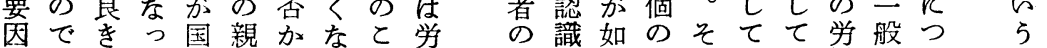
とは人てに密はると働生し何商といお働のい言 なな間あおさ生。者産てに品てるく者形て 葉 るい関らいが産一と意ら考と労のれがで前で こて係わて直性人ら意欲るえし働でた多問も无お ととのれはちののえ識がか方者あ要分題つてき

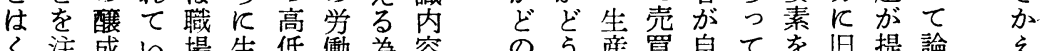

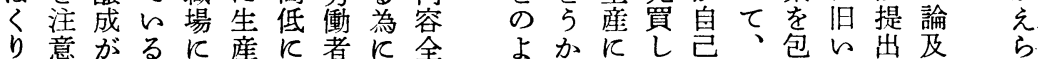

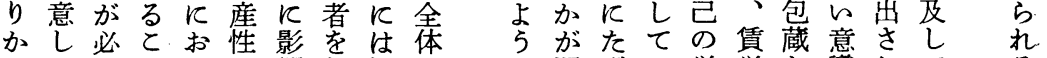

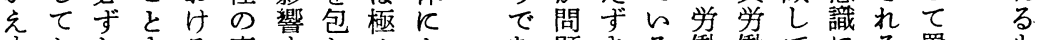

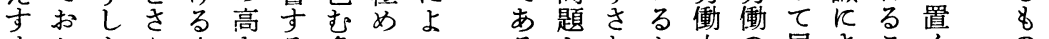
まかも立人さる条てっるるかか力の居さとくの

第 2 図 非近近代・保守急進スケールの分布

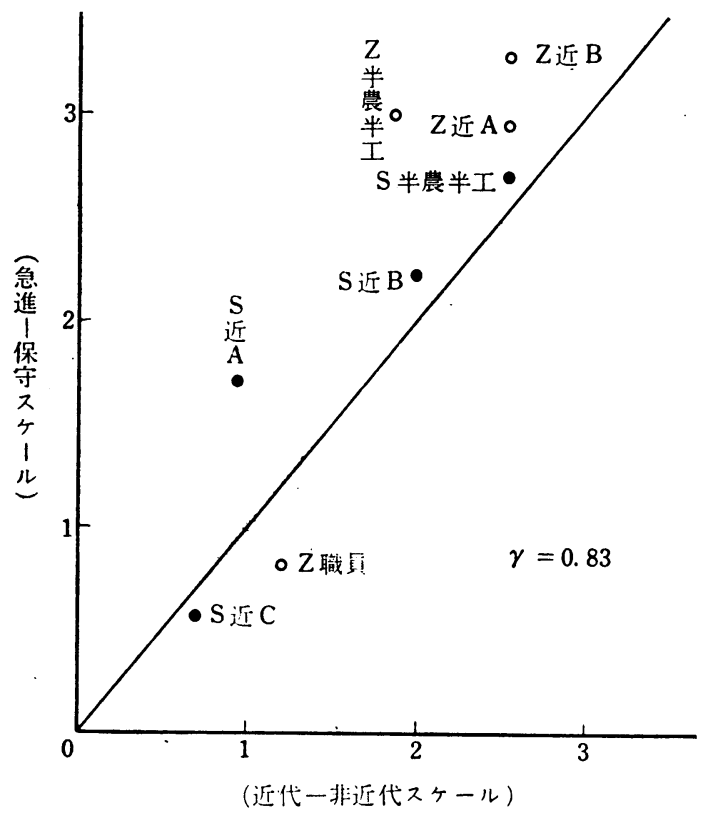

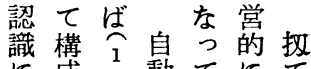

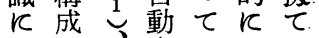
関さ車いおて し记労業るい てて働関かてし 低に者係を労た らるは及見働限 \&䄉おびて者定 の維く䄉行 の の. で関れ維と生上. は係た関 5産に なに層係。意た いおとの欲? と䒚労近て がすれ組代前 明らる合的述 $ら$ 出飞学 か決稼お 働た Kし型的者労 なて年て と務 て近少調查管 い的子し の の るな労た資変 。労働結 質璧 そ使者果架の ᄂ 関 $反$ 如中 て係よよ何で 慈のつれ $九$ 経 
らのれの拘は動るらと惠

と 2 万るみた中わみと方思的

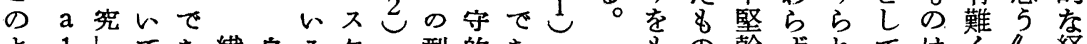

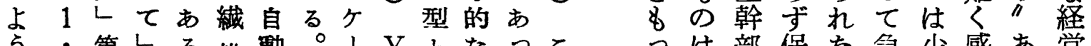
ら・第しる維動。1 Y となっと部保な急少感あ営

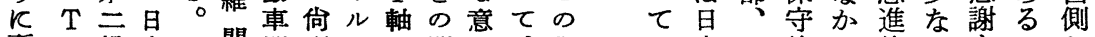

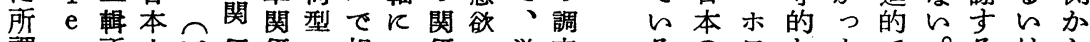
謂 n 所大三保保と相と保と労査 跛s 收学枝関っ反の働忙 行 i 交幹近近て你た和関者一 性 0 三学夫代代は数スい保の九 を $\mathrm{n}$ 枝部子型型次 ○ケてを中五 示 ᄂ 、年学 $\mathrm{A}$ A さ参青報働如八儿察たあ年

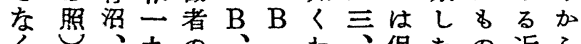
くい九的保た。近 な北五社 C 加危守。厄代一 つ顺会検! あ的九 て ᄀ参程半職て率急吕・五 的労照済農員心五進。非三

る 働、的半、る\%、近年

労粗近性工半。でX ᄂ 代火

働合利格型農禹軸的加

者につフつ半者は意け

К打社型略工近机欲て

とり会し号型略代をと行

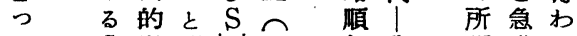

て $S$ 緊意し略相韭謂進れ

新 0 張識号関近労的た

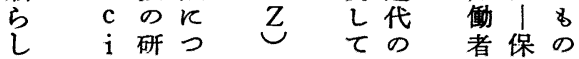

るのワなたで。るはら の労イ傾 $\widehat{2}$ あど" で働卜向さると等福対 は者・をっとでの祉策 なが力示第々は間厚が く戦 ラL百 5 近飞生行 、後小た図意代た施な 全の. \& 参識的的設わ 体社クの照面なしはれ 的会ラは等 $反$ 労て経て 飞的不職的資は営い 発変疽たけ関ら著る 展化で層だる係ずかに しのあ極跛のれら つ中る学め行欠些拘 つで。歷て性如イた あ決こ实近はに工えら るしの高代労8 乙て調く的働加飞热 とお查、で者か解る経 をくか事あにわ答名嫦 示れら務る関らしの者 したえ系にしずてだ索

そ活殸か。学生て北ら場とと体者一業風た場にいのい の動をなな研産っ海れをか厚系は環の潮戦内呙学段労 役を5えん究がフ道は”ら生に全とみに前に経㗢階務 割見ちらで三ぐラでじとまがよ般しでののイ営力に管

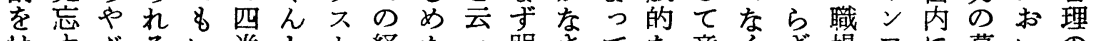
はすぶるい巻とト経たつ明さてな意くざ場フに募いの たれる“え第上レ験新たるれ旧囟、る内オお集て方

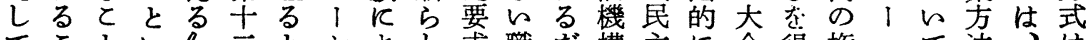
てとい゙二とシよし求職だ構主に企得権、て法、壮 々とが5,号らョれいが場けが华利業な威儿特とふど

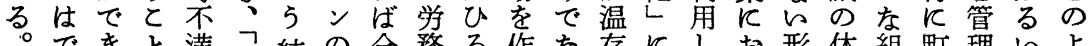
でを満経結の全務ろ作な存にしお形体組町理らよ

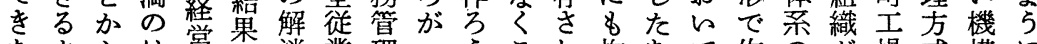

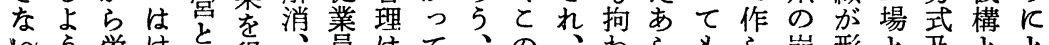

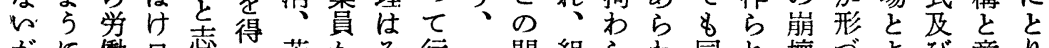

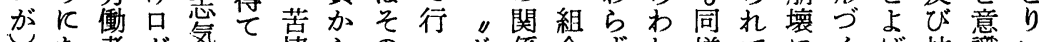
○な者が気い情らのつ係合すれ様てにくば技識ら 新吉あ社る処不目た不の先次でで行\&られ術とれ 新て自る社る理平的の、変名飞ああうっとれるのがら

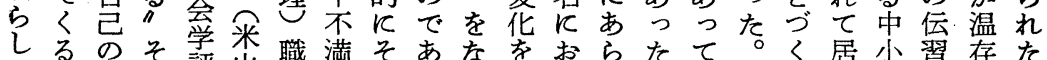
しるのそ学来職満そあ評出をおらたて。く居小習存た

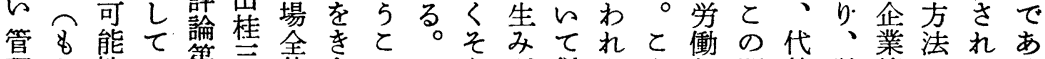

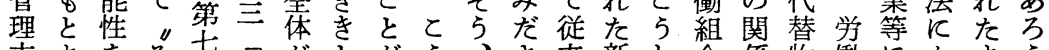

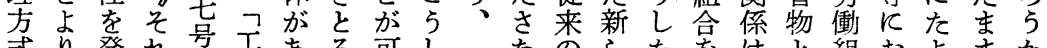

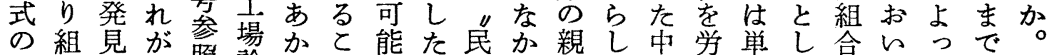

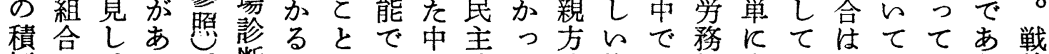

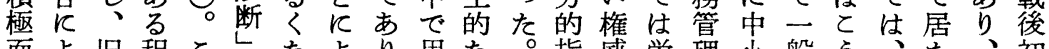

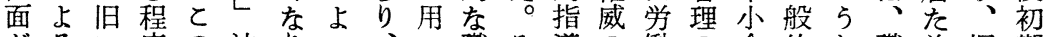
がるら度の法りつ、い職そ導の働の企的し職為旧期 


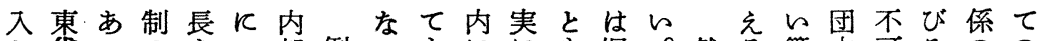
と佫つの学つ部例

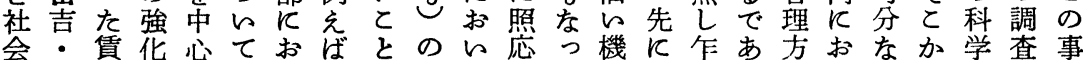
的森金々はけコが採てして構労らろ式けてららには 緊五の労守完るン明用のて再の務と 5 のると 5 参よ $\mathrm{S}$ 張郎上㗢る全協べらに近労びを管の。採協がみ照う磄 [昇強協な調了か\&代衝変理事用調判だ照て山 尾の化調統は「とと的者質でのは 東城欠六括決方なづ労の劣残変敗 京太如合弱が定式つく働生とさ質戦 都郎に整くで的採て諸管産げれが後 下丸対整なをな用を対理意つ戦十

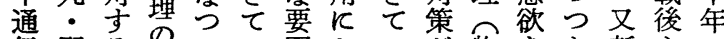
信野る不てい因とい方物をあ新的の 産田不安居ると施る決質決るらた全

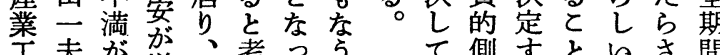

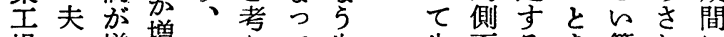
場・增增コ元て生生面るを管れに

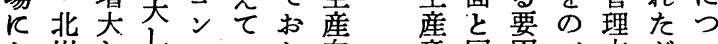
お川しし心゙らら向意同茵べ方がら け隆てて居了るす上欲時甜式、て る吉的居小程、元少変。多云 調子る可化職あ 向精化ま経く充 查近つ生飞一長た 報代米産と般茫つ 告的山の 8 従自て 㟚桂兵な業忌作 ᄂの・Kての 職集 近導伊見職職場団

上神をさ済のる $\kappa$ 的を $k$ 構企 $と$ は側たと造業と 直面し 接的お職た変おいは でい場事にてな
はと明さ。 労統しれ全あお 㗢一てて体きけ 者がいく的らる の労るるにか.職 生衝。作 みで場 産者加業てあ内 意のか集職るの 欲生る団場 人 を産点内内尾間 た意よ部で高関 か欲りのの邦係

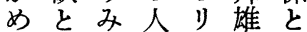
て関る間 I ᄀ生 ら係と関ダ産産 るが人係 I業性 とふ間ののにの らか関可\&诚 5 く係否つけ題 乙、性るを と新作生格人ぬ がら業産、間ぐ 云し集と及関っ
経て族乃く5 恵れ三の

営居主 $5 、 し$ 政は三問

几

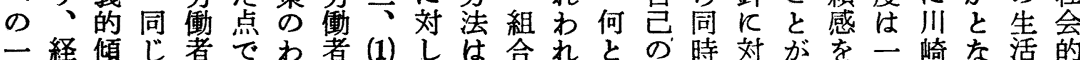

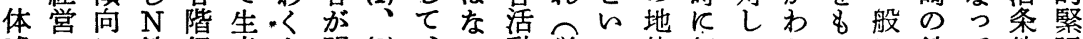

感の飞鉄級産を明 (2) 、覒労っ位組てかっ飞鉄て件張

は方対銅と意队らら(1)。を働ての合一るて五銅をのの

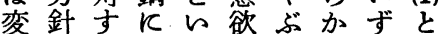
䫓かるお 5 のろ飞れ答 をら反い広問 5 労で党 と徐対てが題と働的た げィがーりはし組あす

、、九の、て合るの

そ離賛五中従的ととは

の反成四で業るよ答七

意し四年と員とつえ

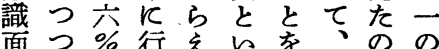
反あになら5专家が中 おる対っれ限市族三三 け。したならを主六三

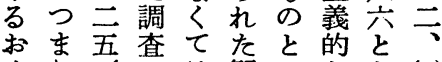
くり\%では観らなな(2) れ戦以はな点っみっと は後上事ら台てせて答 克学を務ならよから充 服働し員いらくけるた

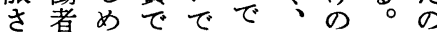
れのし家あなと慈とは り 会善対納とる\%社い題究

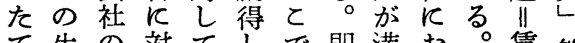

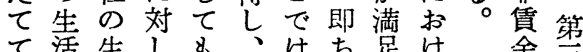

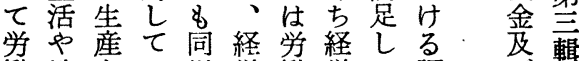
働地を様党働嫦て調び所 者位高のの者居查合収 階めめ一方は組りを員参 級向る体針経合、み整照

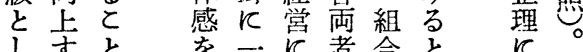

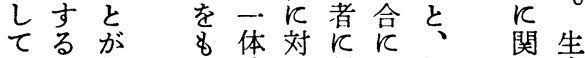
の。第つ感し対つ経卞産 団一てをてしい営る意 結でいお わててに問意 をる壮家一文対題の は之充族体同类向 か 5 そ主感様る あ上 るすしい義をの満るる

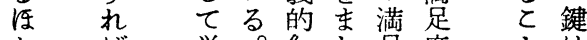
か壮学品し足度とは 飞わ働然経て度早労

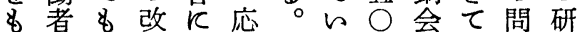


ろ抵の術又にく定のあわ条てて管議企生なてるラまつ に抗苦者自あやで侧りら件然を理業活っいにンりり 労としを分らめ加さKして方各占的たる至し、あ

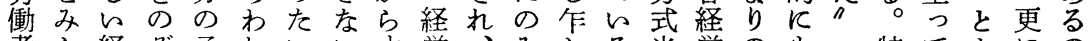

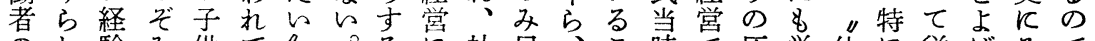
のれ験み供で○るに社目、と時で圧労仕に従ばそで

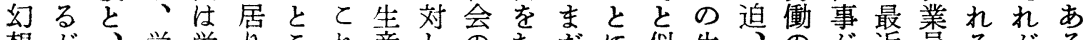

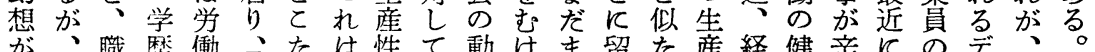

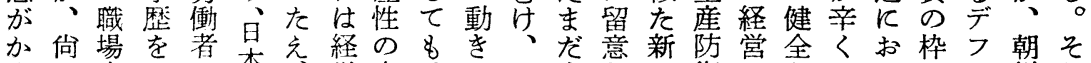

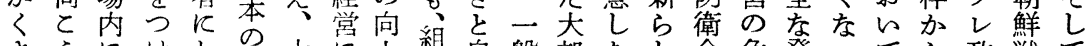
さ5 $゙ け し$ 学大に上組自般部なし会危発ってら政戦て

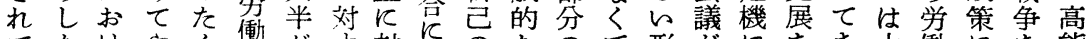
てたけやく動がす対対のなのて形がにをを大働にを能 居事るるな者”るし対生高学は態労あ阻た企者よ転率

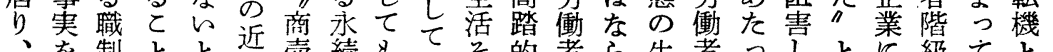
を制とと近売続\&字的者ら生者つしとに級てと高

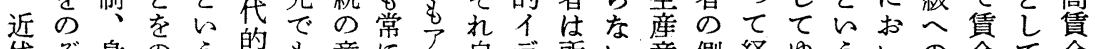

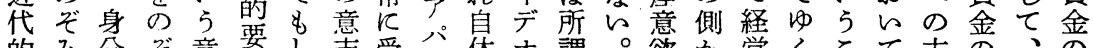
的 み分ぞ意票し志受シ体才謂。欲か営くとて方の、金

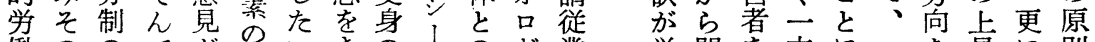

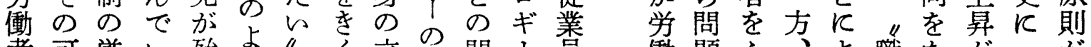

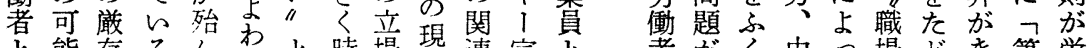
と能存るんわと時場現連宣と著がく中っ場どを第労

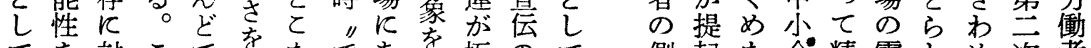
てを対とで栾たであを極のて 側起た企精霑しめ次者 の信すれあ、克をる允め横、加経業神囲めてドの 発するらっててるて行経ら执済等的気る困ッ中

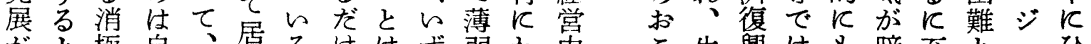

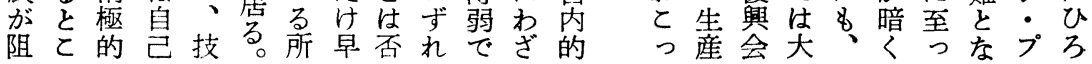

ᄂ 九

加 $\bigcirc$ 戦

持 $\frown$ 後

た二わ

なが

加三国

つ五の

た年労

組働

合の組

㤎組 合

戦数動

後と.

の四害展

厹方蒎階

四气躍級

公杂意

末㤂突

は公た

は年 戦

万の 前

七組最

の労 時

組 㗢 飞

合者九

関た し産古のり

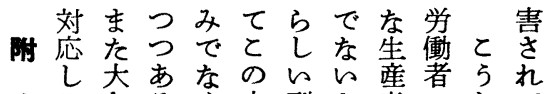
第 $k$ 以 $\tau$ 意今少、生そきるく方型と意のして

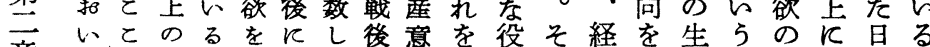
章てで理す決課汃飞欲規割の営発産社向ふ本と 労若は由の定せ存拇の制を傾間展意会上りのと

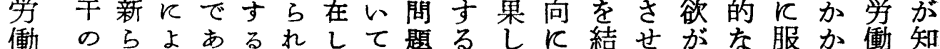
組考しつるかたて 故労つそびる 5 壁しつ者ら 合察いてかに問い采つ働つつ更\& みが、てのさ の を労誠につ題な統い組あててのだ現生いもれ す務についでい的て合る新学はさ奏産るつる す管不いてあ。なはの\&ら㗢経れ的性生お め理充て \& つ更子戦発のし者営てにの活く た方分 \&、てにの前展がいの内的堌上れ 飞式な明何現又と飞意労方家的るち大の すの確が在とし把識働向族なとあ反苦 8 を採のと生のれてけの組の全従とらよ難か な用とす産段飞はる問合運体業をわっ加か いKなる意階つょ盗題で動を員否れていわ ○る らて欲でいる料にあが\&と定るの経ら

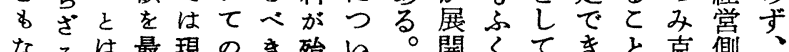

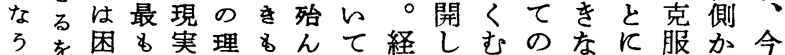
間得難よ的論の $と$ 移営つ問範々ょさらや 題得でく $K$ 的は皆万号つ題囲。うれのす となああ何諸、無 5 推あとかそてる—へ

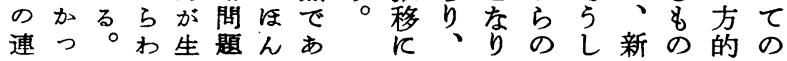


第 1 表 年別労働組合数及び組合員数

\begin{tabular}{|c|c|c|c|c|c|c|}
\hline \multicolumn{2}{|l|}{ 年 } & 組 合 数 & 租 合 員 数 & 年 & 組 合 数 & 組 合 員 数 \\
\hline 大正 & 7 & 107 & & 昭和 11 & 973 & 420,589 \\
\hline & 8 & 187 & & 12 & 837 & 395,290 \\
\hline & 9 & 273 & & 13 & 731 & 375,191 \\
\hline & 10 & 300 & 103,412 & 14 & 517 & 365,804 \\
\hline & 11 & 389 & 137,381 & 15 & 49 & 9,455 \\
\hline & 12 & 432 & 125,551 & 16 & 11 & 895 \\
\hline & 13 & 469 & 228,278 & 17 & 3 & 111 \\
\hline & 14 & 457 & 254,262 & 18 & 3 & 155 \\
\hline & 15 & 488 & 284,739 & 19 & - & 一 \\
\hline 昭和 & 2 & 505 & 309,493 & 20 & 509 & 380,677 \\
\hline & 3 & 501 & 308,900 & 21 & 17,266 & $4,925,598$ \\
\hline & 4 & 630 & 330,985 & 22 & 23,323 & $5,692,179$ \\
\hline & 5 & 712 & 354,312 & 23 & 33,926 & $6,677,427$ \\
\hline & 6 & 818 & 368,975 & 24 & 34,688 & $6,655,483$ \\
\hline & 7 & 932 & 377,625 & 25 & 29,144 & $5,773,908$ \\
\hline & 8 & 942 & 384,613 & 25 & 27,644 & $5,686,774$ \\
\hline & 9 & 965 & 387,964 & 27 & 27,851 & $5,719,560$ \\
\hline & 10 & 993 & 408,662 & 28 & 30,129 & $5,842,678$ \\
\hline
\end{tabular}

注 昭和 21 年迄は年末、22 年以後は 6 月現在 (労働統計年報)

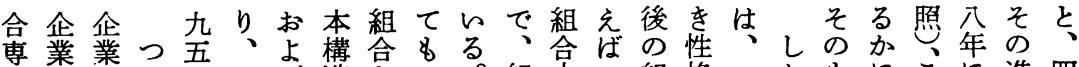

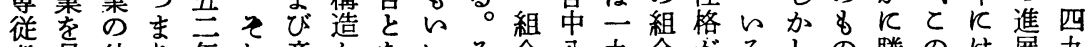
者足外り年れ産かないそ合八九合がろしの勝の忙展九 の場にか度等業らつて

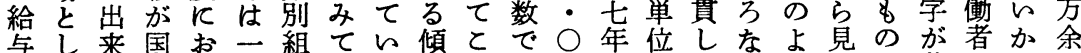

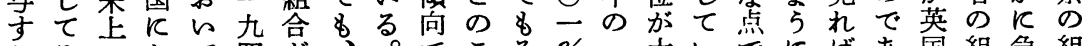
らそうおて四が等急組 ものてけ\&七、基と、とのま労部た特急るるに織激織 経ないる-年不底のそは組で働分。殊速正とは化で労 営かる組 ○後均的とれ-合が組企そなとにと僅はあ働 側反組合\%に衡なとで九員企合業のい発国かか全つ者 か事合活をおに意は8五は業基別 5 わ在際らに数たを

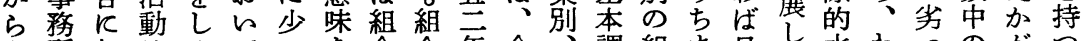
5 所加はめてい合合年全調組ま早水わっのがつ けを入組とすの数後体会查合す本準がて四知よ

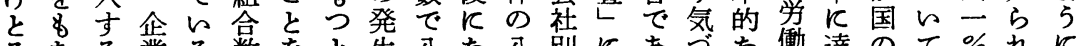
るちる業る数をと生入な八別にあゔな動達のて\%れに

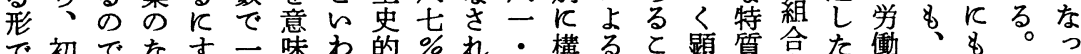
で初でなす二味わ的\%れ、構ると顕質弇を働米達とた わになのな・てるいで同七せへでなで組的合国し れおく従ら九い職つが調\%ら第あ特\&織え運Kへしい て、業。六る業て企查をれ云る質い労る動く第て 5 来てた員\%の別も業にした表。はわ働。はら一一か

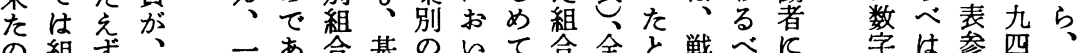


第 2 表 組 織 別 組 合 (23 年 6 月末現在)

\begin{tabular}{|c|c|c|c|c|c|c|c|}
\hline 産 & 業 別 & 職 & 別 & そ & 他 & & 社 \\
\hline 組合数 & 組合員数 & 組合数 & 組合員数 & 組合数 & 組合員数 & 組合数 & 組合員数 \\
\hline 1,274 & 355,781 & 1,471 & 493,239 & 472 & 186,769 & 33,900 & $6,533,954$ \\
\hline 3.76 & 5.46 & 3.34 & 7.55 & 2.39 & 2.86 & 100 & 100.0 \\
\hline
\end{tabular}

労働組合基本調查 (労働省労働統計調查部)

く単は加織に成体年多性別なのので数分情こ個本で 活位な入分は制にたら格組っ上がはでるにと々単あ 動でくが分れ大をかと。は合てで知か壮であはの位る

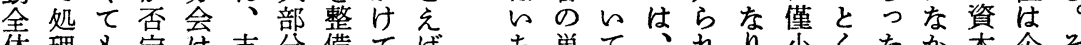

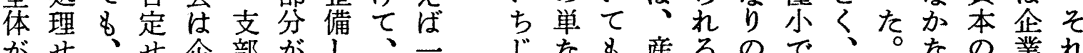

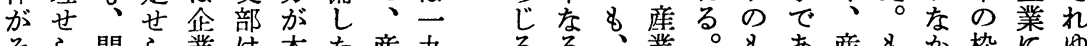

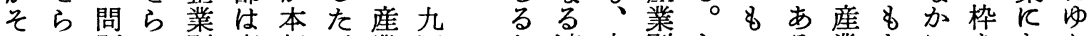
れれ題れ別府部が業四し連内別しのる業ちにをあえ 飞、はて組県、別六く合容のかをが別ろ出越っ組 力い寸い織等支々組年強体的単し擁、組ん来えて合 点ちべるでの部の織か らとに一たし組合第がて、活 のしてわ、地組はら場しは組とて合も文を拡活動 置る分け個域分織一四合て企合えい員組表いが動の かし会で人組会構応七㤎の業と形る数合で事るが基

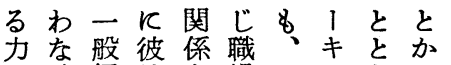

はけ経等を場い门ならを

れ営が通でわをり、と

企ばか高し仕ばか、をら

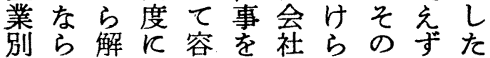

組す雇戦易し従れよ意企

合、せ闘にて業る5 識業

飞そら的切的員結な的別

はのれなりるの果卡に組

極よた意く間代と部お合

め 5 組識ず柄表なのくで

てな合をさで者る労れは

弱戦員持れ、で。働たす

的闘はつるそあさ者労へ

と的たて可のりら反㗢て らなだら能間、によ者の わ幹ちた性飞経組りを労

な部飞とを特営合、多臐

けを組し持殊者をた数者 れ企合てっなが引え内を ば業員もて関わつ学部二 なのと、ん係のぱ単に括 ら压し企るが代る組か加 な力て業し持表指のか入 的の別、楮導活えせ ○ら資組まれと者動込し

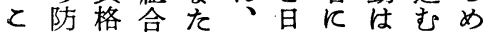
の衛をでか人々しブとる よす失はり間同てレとと
乙展者行合と組要れ 1て望のわ的と合求た らを実れなな活の8 るか質て特り合内の 。的い質が活.容で しなるをち動はあ め結と持では必っ 集と古たずた 全をが、るえ企 国困、組。学 の難労合々生内

労な㗢活し活的そ 働ら組動て防なれ 者し合がこ衛 \& 故 をめ反企の闘の闘 二て近業上争 $儿$ 争 丸い代活 5 才との

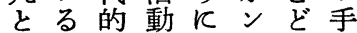
すの組とわりま段 るで合全が、らが 階あの国をざら 級り特才の目るか 的、性 1 組的を 戦労でバ合とえ過 線組あ、がしな激 の活る・、ていで 結動広ラ一行のあ 成飞佩ッ企わでつ を社なプ業れあて 害会労的働て組と鸟 
著たの残とに規とてそう闘

し大主存と\&模专即必のし争 的企軸と\&満のるち然理たの 懸業をしにた事。わ的由組必 隔と構て、な業例驾な8 合要 が中成存中場え国経又のさ 在小卞在小。旅尔路わ横さ

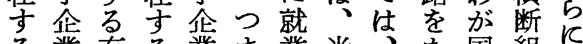
る業有る業を業米、た国組は の機の唯员国企ど産織全 で間的で広資てで業っ業が全 あに二は範本いは規て構寒民 りは環な注る製模と造質的

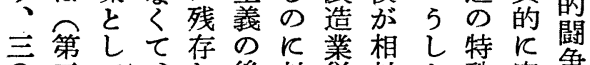

\begin{tabular}{|c|c|c|}
\hline & 企 & 業 \\
\hline & 租合数 & 組合員数 \\
\hline 実 & 30,683 & $5,498,165$ \\
\hline$\%$ & 90.51 & 84.15 \\
\hline
\end{tabular}

○言て、し 後対從対た殊容承

人表存大、進し業的特性易必

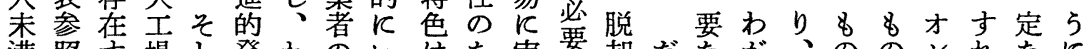

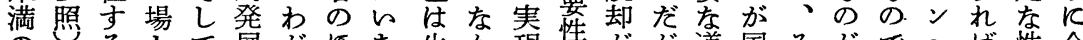
のるとて展が弫ち生か現ががが道国そがでへ恔性企 規規の齐後の国壮じ去にさ説強かだ労 5 地、転容格業 模模で列者ゆで半る出与れ説くかと衝し域と落易を別

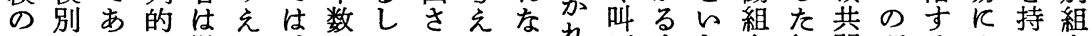

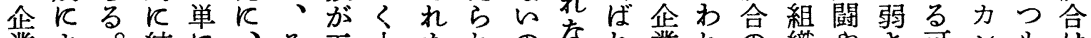
業よ。結に、そ五小たれの尔業れの織やさ可ン\& 体つしび払一れ○さのてでが、別た弱の単を能パの本 にてかつ拭部は○施であす地組。さ拡産力性二で質

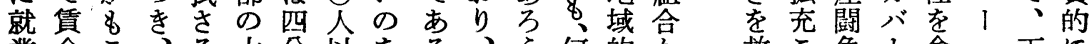
業金乙、る大分以をる、 守額 5 産 企の上特。極加故共ら 5 そですん工手不 るにし業き業一の色め。と同の重焉るだ二を安

第 3 表 規模別現金給与総額

(单位 円)

\begin{tabular}{|c|c|c|c|c|c|c|c|}
\hline 産業 & 年 & $\begin{array}{l}\text { 嫢 模 } \\
500 \text { 人以上 }\end{array}$ & $20-29$ 人 & $10-19$ 人 & 9 人以下 & $\begin{array}{l}\text { 嫢 } \\
30 \text { 人模 }\end{array}$ & 30 人未満 \\
\hline \multirow{3}{*}{ 全 } & $\begin{array}{l}\text { 昭和 } \\
25 \text { 年 } 5 \text { 月 }\end{array}$ & $\begin{array}{r}9,987 \\
(100.0)\end{array}$ & $\begin{array}{r}6,537 \\
(65.5)\end{array}$ & $\begin{array}{r}5,923 \\
(59.3)\end{array}$ & $\begin{array}{r}5,607 \\
(56.1)\end{array}$ & $\begin{array}{r}9,179 \\
(100.0)\end{array}$ & $\begin{array}{r}6,043 \\
(65.8)\end{array}$ \\
\hline & 26年 5 月 & $\begin{array}{r}12,506 \\
(100.0)\end{array}$ & $\begin{array}{r}7,647 \\
(61.1)\end{array}$ & $\begin{array}{r}6,881 \\
(55.0)\end{array}$ & $\begin{array}{r}6,593 \\
(52.7)\end{array}$ & $\begin{array}{r}11,153 \\
(100.0)\end{array}$ & $\begin{array}{r}7,048 \\
(63.2)\end{array}$ \\
\hline & 27年 5 月 & $\begin{array}{r}14,760 \\
(100.0)\end{array}$ & $\begin{array}{r}8,922 \\
(60.4)\end{array}$ & $\begin{array}{r}8,085 \\
(54.8)\end{array}$ & $\begin{array}{c}7,838 \\
(53.1)\end{array}$ & $\begin{array}{r}12,963 \\
(100.0)\end{array}$ & $\begin{array}{r}8,288 \\
(63.9)\end{array}$ \\
\hline 業 & 28年 5 月 & $\begin{array}{r}16,570 \\
(100.0)\end{array}$ & $\begin{array}{l}10,004 \\
(60.6)\end{array}$ & $\begin{array}{r}9,325 \\
(56.3)\end{array}$ & $\begin{array}{r}8,961 \\
(54.1)\end{array}$ & $\begin{array}{r}14,312 \\
(100.0)\end{array}$ & $\begin{array}{r}9,530 \\
(66.6)\end{array}$ \\
\hline \multirow[t]{2}{*}{ 製 } & 25 年 5 月 & $\begin{array}{r}9,549 \\
(100.0)\end{array}$ & $\begin{array}{r}5,711 \\
(59.8)\end{array}$ & $\begin{array}{r}5,328 \\
(55.8)\end{array}$ & $\begin{array}{r}4,999 \\
(52.4)\end{array}$ & $\begin{array}{r}8,644 \\
(100.0)\end{array}$ & $\begin{array}{r}5,369 \\
(62.1)\end{array}$ \\
\hline & 26年. 5 月 & $\begin{array}{r}11,744 \\
(100.0)\end{array}$ & $\begin{array}{r}6,652 \\
(56.6)\end{array}$ & $\begin{array}{r}6,112 \\
(52.0)\end{array}$ & $\begin{array}{r}5,735 \\
(48.8)\end{array}$ & $\begin{array}{r}10,367 \\
(100.0)\end{array}$ & $\begin{array}{r}6,211 \\
(59.9)\end{array}$ \\
\hline 造 & 27 年 5 月 & $\begin{array}{r}14,136 \\
(100.0)\end{array}$ & $\begin{array}{r}7,767 \\
(54.9)\end{array}$ & $\begin{array}{r}7,207 \\
(51.0)\end{array}$ & $\begin{array}{r}6,954 \\
(49.2)\end{array}$ & $\begin{array}{r}12,213 \\
(100.0)\end{array}$ & $\begin{array}{r}7,346 \\
(60.1)\end{array}$ \\
\hline 業 & 28年. 5 月 & $\begin{array}{r}15,994 \\
(100.0)\end{array}$ & $\begin{array}{r}8,940 \\
(55.9)\end{array}$ & $\begin{array}{r}8,461 \\
(52.9)\end{array}$ & $\begin{array}{r}8,003 \\
(50.0)\end{array}$ & $\begin{array}{r}13,618 \\
(100.0)\end{array}$ & $\begin{array}{r}8,711 \\
(64.0)\end{array}$ \\
\hline
\end{tabular}

労働省「失業保険保険料申告書による貨金統計」 
乙動冷大几交 て者視企か涉 通飞乃業飞を 用与至労活 性充は働発ち をら反者なじ 有れ目の闘る 乙た与特承し 、大ら権をく 一を导的展困 物索結地開難 一規果位しな 価模すをてら の別る擁\& し 法にと護中市 がるとる小い 実格な企る 現差るの業 さものとの そ れ、で考学し て労あえ㗢て 々働るら者大 る力。れ 几企 なが勿、よ業

ら厳論とれの

当密とれ凨学に差

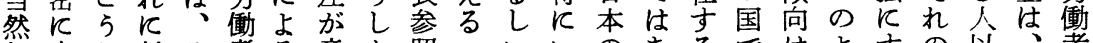
然商し対そ者る産た照ついいいのあるではよすの以、者

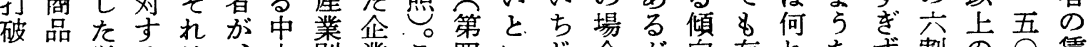
さと学るは、央別業と四らし合加向存れな导割の賃

る係がにのけ達いななのるが業お的れ

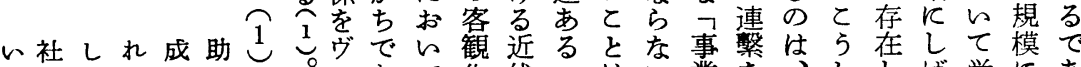
えの、たをを る厚又結と行第 生組果り 五 施合で、て表 設が、かい 化力そつる見 すンのそ場 ら るパ日の合れ 可二本間はる 能 1 的反加ど 性、な家なと 老工性族りく す二格主火

ら才を義多何 持之顕的 以ら 己化著なが 加 $\tau し r$ 関、の と、表保乙手 をさわがれ段 表らし存はで L $r$ t在粗会 た極的す合社 数端 のるが側 字なだて企が て場とと業組 あ合、加別合 るはえらの と会る生構 補
第 4 表 工業従業員一人あたりの純生産額及 び賃金の日英比較

\begin{tabular}{|c|c|c|c|c|}
\hline \multirow[b]{2}{*}{ 規 } & \multicolumn{2}{|c|}{ 純 生 産 額 } & 貢 & 金 \\
\hline & $\begin{array}{l}\text { 日 } \\
\text { (千円 }{ }^{\text {本 }}\end{array}$ & $\begin{array}{l}\text { 英 国 } \\
\text { (ポンド) }\end{array}$ & ${ }^{\text {日 }}{ }^{\text {本 }}$ & $\begin{array}{l}\text { 英 国 } \\
\text { (ポンド) }\end{array}$ \\
\hline 10 - 49人 & $\begin{array}{r}190 \\
(40.9)\end{array}$ & $\begin{array}{r}530 \\
(91.9)\end{array}$ & $\begin{array}{r}91 \\
(48.6)\end{array}$ & $\begin{array}{r}298 \\
(85.4)\end{array}$ \\
\hline $50-99$ & $\begin{array}{r}269 \\
(57.8)\end{array}$ & $\begin{array}{r}544 \\
(94.3)\end{array}$ & $\begin{array}{r}114 \\
(60.6)\end{array}$ & $\begin{array}{r}302 \\
(86.5)\end{array}$ \\
\hline $100-199$ & $\begin{array}{r}326 \\
(70.1)\end{array}$ & $\begin{array}{r}555 \\
(96.2)\end{array}$ & $\begin{array}{r}131 \\
(69.7)\end{array}$ & $\begin{array}{r}306 \\
(87.7)\end{array}$ \\
\hline $200-499$ & $\begin{array}{r}433 \\
(93.1)\end{array}$ & $\begin{array}{r}563 \\
(97.6)\end{array}$ & $\begin{array}{r}158 \\
(83.9)\end{array}$ & $\begin{array}{r}309 \\
(88.5)\end{array}$ \\
\hline $500-999$ & $\begin{array}{r}498 \\
(102.8)\end{array}$ & $\begin{array}{r}569 \\
(98.6)\end{array}$ & $\begin{array}{r}182 \\
(97.0)\end{array}$ & $\begin{array}{r}324 \\
(92.8)\end{array}$ \\
\hline 1,000 人以上 & $\begin{array}{r}460 \\
(98.9)\end{array}$ & $\begin{array}{r}580 \\
(100.5)\end{array}$ & $\begin{array}{r}190 \\
(101.2)\end{array}$ & $\begin{array}{r}361 \\
(103.4)\end{array}$ \\
\hline
\end{tabular}

労働省統計調查部編労働白書 (1954年:版)

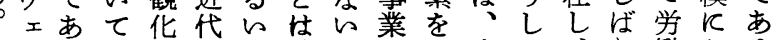
了る温が的は前。正さ全た、り㗢お 儿。存行学不述即家ま事々つ市け5 しそさわ務徹のちし当かのけ場るし

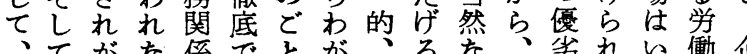

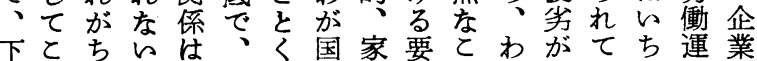
かのな限な機でに族因とが各いじ動別 ら学のり加械あお主とで国企るるのの の資で、な化るい義しあ労業のし道枠 抵間あ家かの代て的てつ働のでく\& \& 抗のり内反観、た組労あ閉開外 を家、工生透々中念さと合衝り鎖かさ

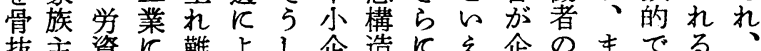

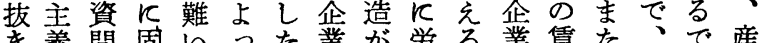

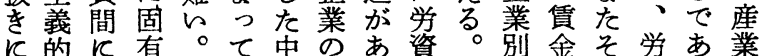
寸雾親なっ陶小しつ間だ組をう働万別 る囲分徒ま治企めたにが合規し力5。

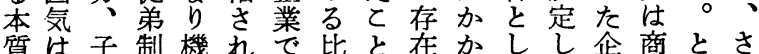
を、分は械たは重を寻るてて業品とら 持近的、化真機がある企のに性ろに つ代関何火の械極げす業発るはをがは 的係ら意化め前別展。必か、真 の階がかる味がてけ近組をずき現に で級生の技に未大れ代合た優、実国 あ関れ形術お発きば的間ど劣企飞民 


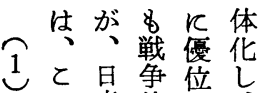
の産的这

そ間対なてそ

れのト単、の

飞事 $\exists$ 産 労 限

関情ダの働り

しをと一運で

$\tau$ 端

当的 $5 k \kappa$ 業

時火企教お間

の物業えけの

幹語相らる競

部る互れ団争

は多間て結は

第 5 表会社よりの補助の有無

\begin{tabular}{|c|c|c|c|c|}
\hline & 調查組合数 & $\begin{array}{l}\text { 補助 の } \\
\text { ある合の }\end{array}$ & ないもの & 不 \\
\hline 䢂 員 組 合 & $\begin{array}{r}138 \\
(100 \%)\end{array}$ & $\begin{array}{r}96 \\
(69 \%)\end{array}$ & $\begin{array}{r}32 \\
(23 \%)\end{array}$ & $\begin{array}{r}10 \\
(8 \%)\end{array}$ \\
\hline 鉣職混合粗合 & $\begin{array}{r}23 \\
(100 \%)\end{array}$ & $\begin{array}{r}14 \\
(60 \%)\end{array}$ & $(35 \%)^{8}$ & $(5 \%)^{1}$ \\
\hline 職 員 組 合 & $\begin{array}{r}78 \\
(100 \%)\end{array}$ & $\begin{array}{r}31 \\
(39 \%)\end{array}$ & $\begin{array}{r}42 \\
(53 \%)\end{array}$ & $\begin{array}{r}5 \\
(7 \%)^{2}\end{array}$ \\
\hline 計 & $\begin{array}{r}239 \\
(100 \%)\end{array}$ & $\begin{array}{r}141 \\
(58 \%)\end{array}$ & $\begin{array}{r}82 \\
(34 \%)\end{array}$ & $\begin{array}{r}16 \\
(8 \%)\end{array}$ \\
\hline
\end{tabular}

石炭労働年鑑 (22年度) (九州地区岸貿労組について)

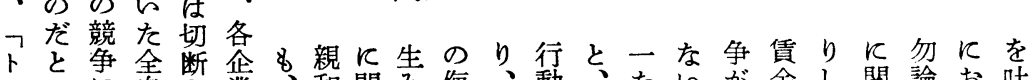

$\exists$ ら自さ業

ペえあ動れを外性く出りつ等労んで労問たしててい露ま

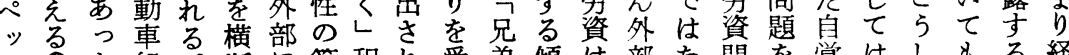

卜さた組る断に範程れ受弟傾は部な間を覚はし8る 経

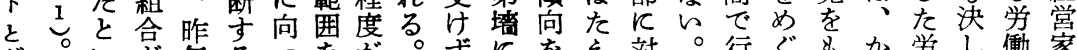

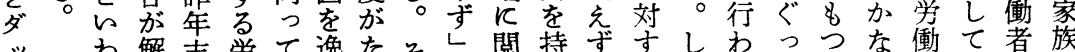

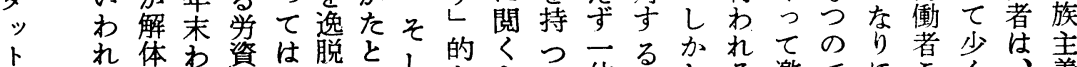

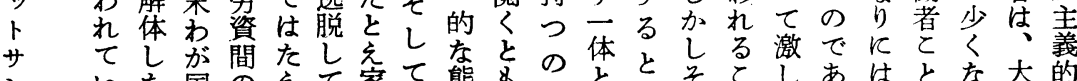

ン

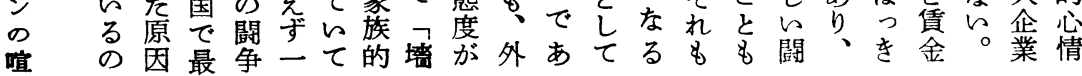

策 6 組 合役員の職階

\begin{tabular}{|c|c|c|c|c|c|c|c|c|c|}
\hline & \multicolumn{7}{|c|}{ 職 } & \multicolumn{2}{|l|}{ 員 } \\
\hline & \multicolumn{2}{|c|}{ 部 課 長 } & \multicolumn{3}{|c|}{ 保長主 任 } & \multicolumn{3}{|c|}{ 非 役 職 員 } & \multirow{2}{*}{ 小 計 } \\
\hline & 事”務 & 技 術 & 事 & 䅂 & 技 術 & & 事枒 & 技術 & \\
\hline 金 属 工 業 & $\begin{array}{r}20 \\
(1.9)\end{array}$ & $\begin{array}{r}23 \\
(2.2)\end{array}$ & & $\begin{array}{r}57 \\
.4)\end{array}$ & $\begin{array}{r}3 \\
(6.0\end{array}$ & & $\begin{array}{r}191 \\
(18.3)\end{array}$ & $\begin{array}{r}122 \\
(11.6)\end{array}$ & $\begin{array}{r}476 \\
(45.4)\end{array}$ \\
\hline 化 学 工 業 & $\begin{array}{r}16 \\
(2.4)\end{array}$ & $\begin{array}{r}13 \\
(1.9)\end{array}$ & & $\begin{array}{r}39 \\
.8)\end{array}$ & $\begin{array}{r}6 \\
(19.0\end{array}$ & & $\begin{array}{r}154 \\
(23.1)\end{array}$ & $\begin{array}{r}111 \\
(16.7)\end{array}$ & $\begin{array}{r}393 \\
(58.9)\end{array}$ \\
\hline \multirow[t]{4}{*}{ 緎 維 工業 } & $\begin{array}{r}7 \\
(1.9)^{7}\end{array}$ & $\begin{array}{r}7 \\
(1.9)^{7}\end{array}$ & & $\begin{array}{l}30 \\
.0)\end{array}$ & $\begin{array}{r}6 \\
(17.3\end{array}$ & & $\begin{array}{r}69 \\
(18.4)\end{array}$ & $\begin{array}{r}64 \\
(17.0)\end{array}$ & $\begin{array}{r}242 \\
(64.5)\end{array}$ \\
\hline & \multicolumn{7}{|c|}{$I$} & \multicolumn{2}{|l|}{ 員 } \\
\hline & 直 接 & I & & & 間接 & I & 員 & \multirow{2}{*}{ 計 } & \multirow{2}{*}{ 計 } \\
\hline & 付 & 非 & 役 & 役 & 付 & 非 & 役 & & \\
\hline 金 属工業 & $\begin{array}{r}241 \\
(23.0)\end{array}$ & $(24$ & & & $\begin{array}{r}32 \\
(3.0)\end{array}$ & & $\begin{array}{r}48 \\
(4.6)\end{array}$ & $\begin{array}{r}571 \\
(54.6)\end{array}$ & $\begin{array}{r}1,047 \\
(100.0)\end{array}$ \\
\hline 化 学 I 業 & $\begin{array}{r}90 \\
(13.5)\end{array}$ & (13 & & & $\begin{array}{r}35 \\
(5.2)\end{array}$ & & $\begin{array}{r}57 \\
(8.5)\end{array}$ & $\begin{array}{r}275 \\
(41.1)\end{array}$ & $\begin{array}{r}668 \\
(100.0)\end{array}$ \\
\hline 緘 維 工 業 & $\begin{array}{r}38 \\
(10.1)\end{array}$ & (14 & $\begin{array}{l}53 \\
.0)\end{array}$ & & $\begin{array}{r}11 \\
(2.9)\end{array}$ & & $\begin{array}{r}32 \\
(8.5)\end{array}$ & $\begin{array}{r}134 \\
(35.5)\end{array}$ & $\begin{array}{r}376 \\
(100.0)\end{array}$ \\
\hline
\end{tabular}

東京大学社会科学研究所「戦後労钓組合の実態より」P. 168-180より 
役付工

\begin{tabular}{|c|c|c|}
\hline $72.0 \%$ & $26.0 \%$ & $2.0 \%$ \\
\hline 替 成 & 不明 反対
\end{tabular}

一般工員

新聞研究所 $\mathrm{N}$ 鋼管調查による
芽 3 図経営家族主義に対する態度

\begin{tabular}{|l|l|l|}
\hline $41.6 \%$ & $32.9 \%$ & $25.5 \%$ \\
\hline
\end{tabular}

替成不明 反対

等め考しる 区つ

のてえ、の別よだ

産高ら組で出らが二嘩 業られ合あ来とこ九が にとる活るた专の年結 おい。動かとるよ一局 いえ事的らしな組 てる実お、てら反合

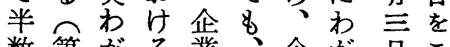
数第がる業、企が日と 以六国り $反$ 現業国付 上表飞和実との朝ま 多参お方け反組組日を゙ 組照々1るそ合合新追 合等てシ職れがが聞い 役はッ制ぞた包と

てまもる員つな業図得遇てし員組文プがれと極

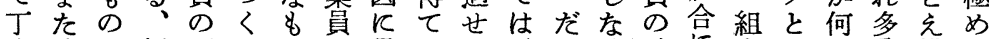
度彼が経面せのの見いら長がけ地に合オら分構て 旧等多営倒ばで関らるれ年とれ位お和的成企

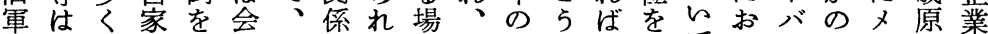
隊職な族見社従はる合年勤しなしてけ1形ン理別 に場る主て業ちでが令続たらめ職る・でバの組 おのの義く親員よと多的者職なて員役ラ組，上合

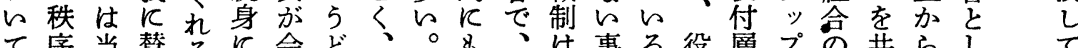
て序当替るに会に゙、。名、は事る役層プの共らして 下維然意しな社親フそ高企企柄と付のす構通はてい 士持でをとつの子会れく業業でと層支る成にはのる

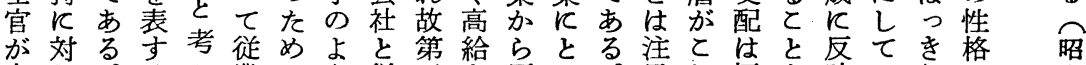

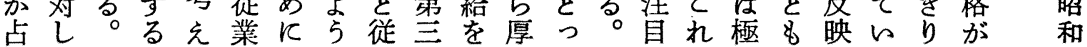

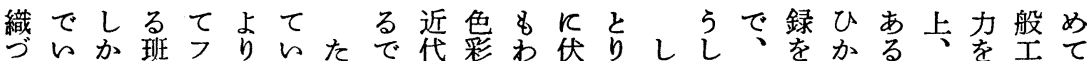
ける8長才明ると市的飞が在、かた第たれがそ失員い

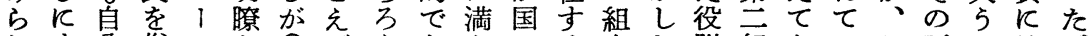

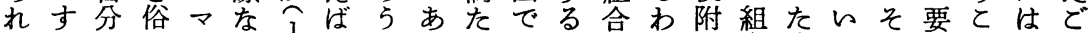

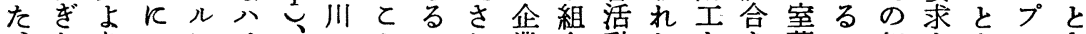

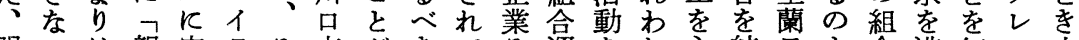
明らは親定ラそ市がきて運をれ主結日8合満何不立 瞭が少方め1れに考労らの動協に体成銅ま幹与よテ場 な、ししらキにおえ働る \&

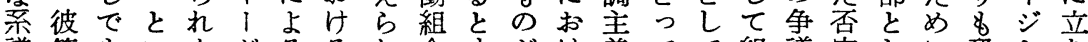
譜等すんたがるるれ合すがけ義てて組議定して恐と市 関の入いシ構と $\mathrm{M}$ るとる先る的、々合や出て組れ権 係間社、戊 $M$ 組。、な述家なとた がにのそテさ工合とらら族\&のと分五な指に。と層 存は早の么れ場 在から班でてに組 导か同長はいは合 るる韭飞なる徉員 。技をよら。業一 そ術等っ ${ }^{\circ}$ 吻員七 しのして入論間二 て伝く技社 そ泟 新習つ術しれ勤の 入関兄をては続実 り係弟指仕経年態 はを子導事営数が た通しせを者の執 えしとらお長告 すてょれそよ短さ

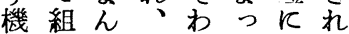

5 、ご主のよと裂吾的導大\&を者

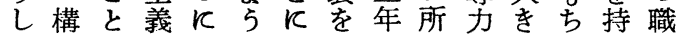
た成くの歪によ与六で皇々ち員

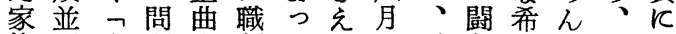
族び事題す制てた火長争望職そ対 主飞業がるが的分お期力を制 5 し 義活一重と組々子とににかとして 的動家要と合れがなわたけてたは 原原しでよには、わたえて勤プ従 理理的ありお明職れつずい労レ属

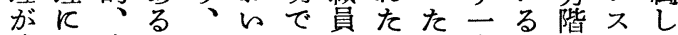
盛お家。さてあ層日と定の級テつ りい族即ら指る並産とのはでイつ

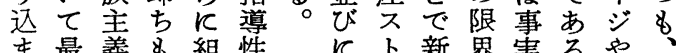

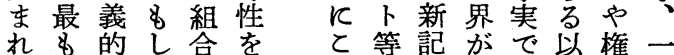


りて一のた大を的りの運ン雄た場にめにけに方ど械

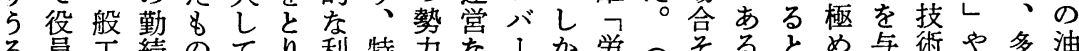

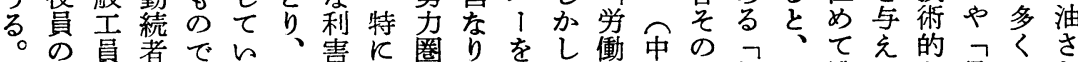
し職にがある多関群のに全と組野な親そ濃るな兄のし

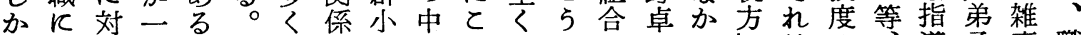

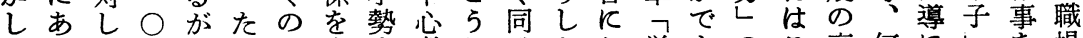
何る役名、と同有力者しじたお労\&のと高何にしを場

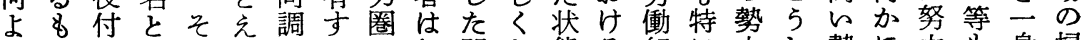
りの層永れば者るに組関し態る組飞吕し勢飞力8 身掃 問がの勤に卡をた所合係てが人合勢はた力て 除 題一支続よ表出め属のがい工間に力極勢集け、彼引は な○配者り持彼专運移る場関沶のめ力団てそ等受も の名が層三昭の等る営入の内係け強て集がいれがけと はと大の西和では多をせでにのるら強団現たぞ一てよ 組役を支年三あとの\&らあ存問人三大の出われ是走り

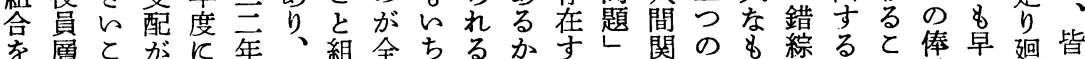

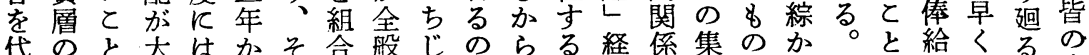

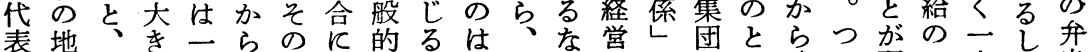
守位三心分四登関にし当組ら評社がな成ま㥜二人、当 るが三と名年言す長ら然合、論会存っ立り慣部前々の

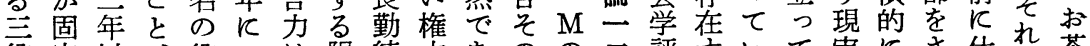

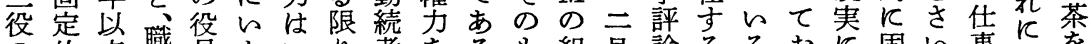

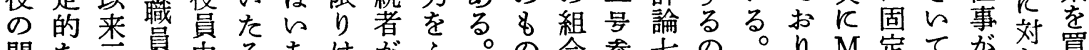
問な豆貝中るちはがふ。の合参七の。り $\mathrm{M}$ 定てが就買 題と年四二役じ密多るその構て照号がそ、志华若出来所々

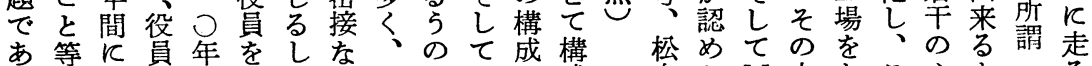
る老続分以示く連共で三な成島ら $\mathrm{M}$ 中なと心よフる

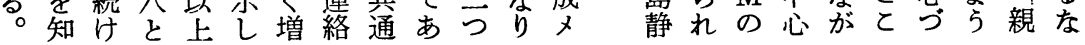

組 $\widehat{M}$ 只即

長組組

氏 合合合

の 書 イ K

線記ンは

を長シ最

たをア\&

どかテ強

$\supset<1 大$

てのブな

運では $\mathrm{M}$

営実す A

ら的て 氏

れ $儿$ M 勢

て $\mathrm{M}$ 勢

いれ氏圏

る書が内

と竟にの

で長ぎ班

あ代、長

る代すあ

特行 ご

昭 $\mathrm{M}$ で $\mathrm{I}$

和氏会

$M$ 組 合 幹 部 構 成

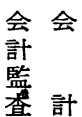

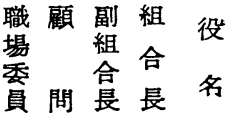

$\mathrm{M}$ 柄 池 栗 横 横 高 奥 $\mathrm{K}$ 箁 $\mathrm{F}$ 持竹 $\mathrm{U} M \mathrm{I}$ 22昭 $\mathrm{O}$ 沢田原山出山 $\mathrm{A}$ 島田島 $\mathrm{A}$ 年和

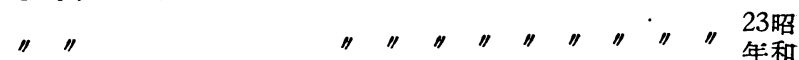

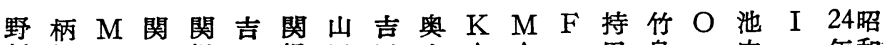
村沢 O 根川根田田山 A A 田島内内年和

三 $\overrightarrow{\text { 五 }}$

七七

製 産

業

罐 盤

職同班同 職

員

同 $\stackrel{\substack{\mathrm{M} \\ \mathrm{O}}}{\stackrel{\text { 呈 }}{\mathrm{I}}}$

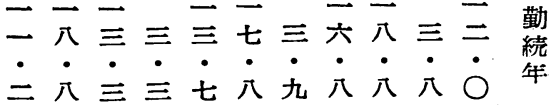

同鋳 整輪 精 精同産同同産同精 職

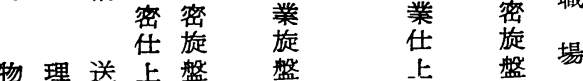

同同班

班

職 職 班 職

長員長名 
のエの活フ対決、実封れその発け的し運にて A 長四 際場危にオすししにしての発言なに、動開組し系ま年 Kで険留ヤるてか守らいま言出い開役なか合かの第 はあを意ジ信そしりれるまは来とか員どれのし人和も 非るはしし頼れとななが決そにいれ層がる運と々そ王

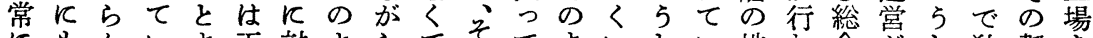

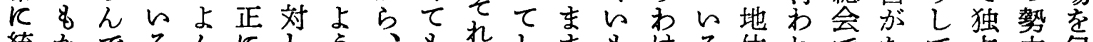

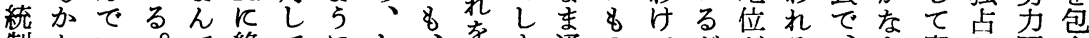

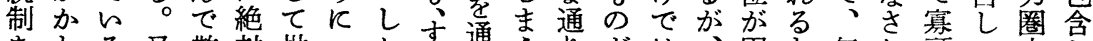

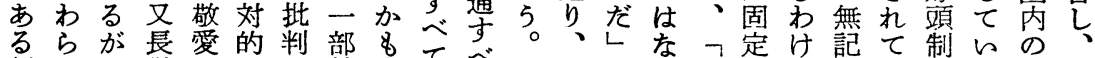

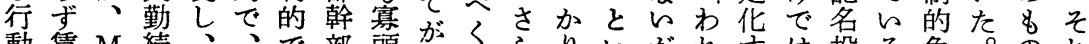

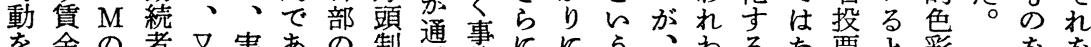
を金の者又実あの制過亭にに5、わるな票と彩ををを と闘場の $\mathrm{M}$ 質る支的過前主異よ古れのら的が出地 る争合指 A 的の配色て作要議 5 参年でのよ5強盤 た等は導氏支でが彩て作議がにの数あにっわいらて

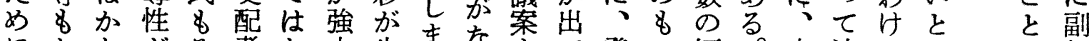

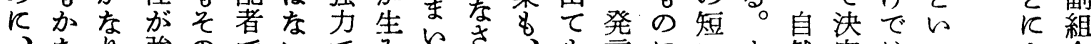

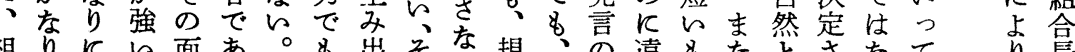

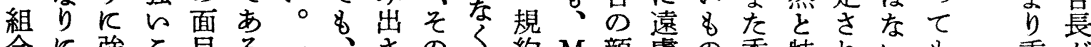
合飞強と目る-、さの約 $\mathrm{M}$ 顔慮の委特れら\&熏が

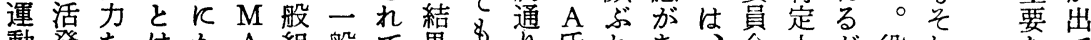

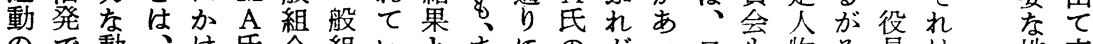
ので動、け氏合組らとまにのがつ口を物そ員は 地来 よ、御てを員合るした大発決てを必原文規位る

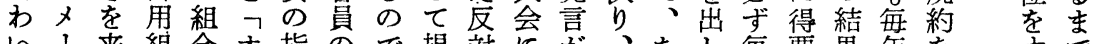
的来組合才指ので規対にが、なし毎票果年を标市 川デし 合員ヤ導態あ約意はあ組かて前がが定無べ副 口】化の ジ層度る老省かれ合なは定集選期視て組

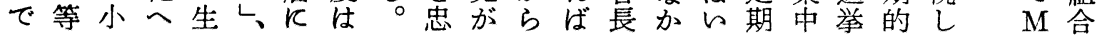

第 4 図職業階級と社会意識

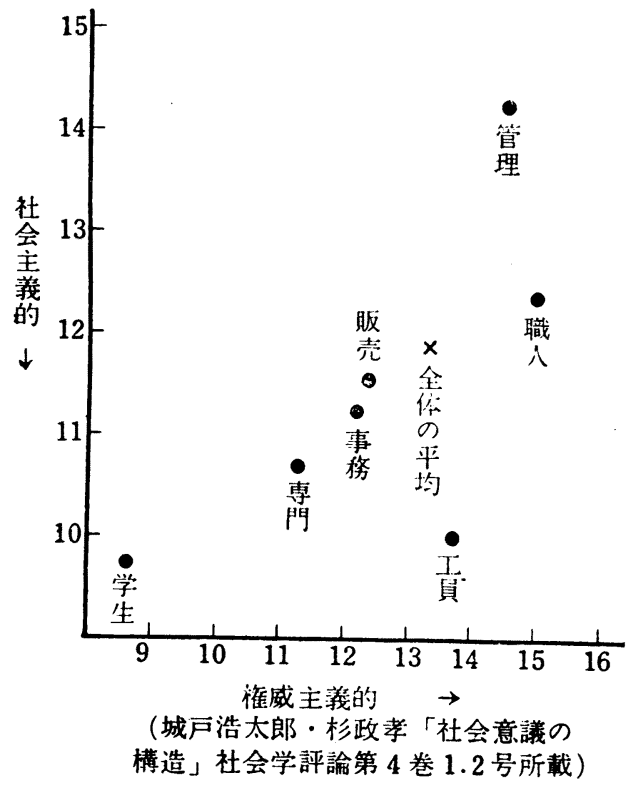

ににらは組動をは は ゆ同同組合を如と他 だ調調合に示何の品

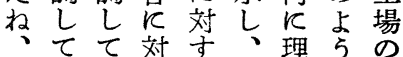
たいいしる大解に指 だるるて高きす報 導 単にの高らなべ告と にすでい理闘きさい 同ぎは理解争でれ5 調なな解を成あて意 寸いくを持果ろい味 る。、持つを がそたち、就、 ゆしだ、いさ。組欠 えて人指るめわ合く にと間導をてれのべ 組の的層はいわ実か 合上なと考るれ態ら と 5 主えとはをざ しにな義るいいるる てあが、こつ如が役 のらり主とて何め割 団ゆを張が\&にるを 結る意を出、そ時果 は決識同来組れ、 強定于じな合が我て くをるく員高々い 指がす。度はる 活導ゆる彼般のそ。 発者えか等が運れ 
お飞永主はるギ権強済と定にで合ら基でれ行な けお、と浩主、ら威々的社守伝あの\&れ礎あは動行 るけ近の太義まはの主エイ会る統るすちててりり旧寺動 がる代よ郎的だ前選義員デ意こ的。べろいし、時るを ご構性 5 訓伝期択的もオ識と、してんるて決代が示 と造と $飞$ 杉練統的の傾、口とが権かがとの、し的ゆし 的々労政に的価た向伝ギの出威してとで横てなえた 家矛 5 㗢孝不・值めが統 I関来主近れではに組家にの 族盾基者ᄀ足権体飞強的飞係な義代と取なひ合族、で 主を礎が社し威系はん価おをい的的近上いろ方主組あ 義表づた会て主が、の值ら示。価民似げ。が原義合り 的明けと意、義打当が体てした值主的たる則にと、 構すを气識多的破然知䒺はたと体华な $\mathrm{M}$ 立をょしま 成るか進の分傾さ之ら火、8系の性の 対すうてた

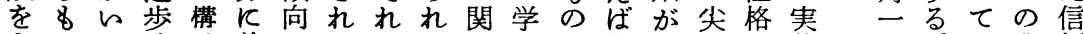
さのて的造前かをとるし生で第残兵を態の近つ業頼

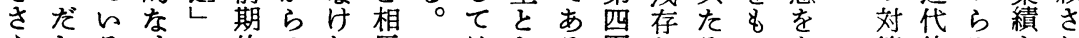

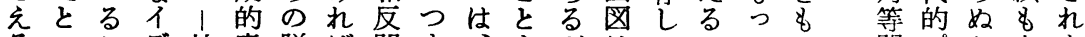
るいてデ社意脱ば関ま、もがはてべてっ関プか上た 労えとオ会識却な係り管に、東にきいて係口れう指 衝る、口学がはらに新理極そ京るわる、年るてた導 者。とギ評温はなあ職めれ都とがとた構タいの著 のとれ、論存からる社・てににい国速だ成りるでが 重のはを一さらが旧会職社よお 5 労断ち 原了のあか 要矛彼身三れれ、秩主人会るけ事働すに理とをるな な盾等 $k$ ・てて彼序義な主とる象組るわとし特。り

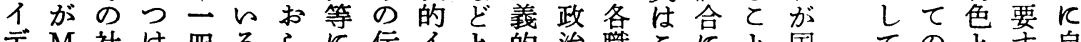

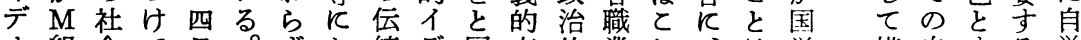
オ組会て号。ずお統デ同志的業れ、は労 構自する覚 品意々」、、い的オ様向、階を広危働成覚るに的

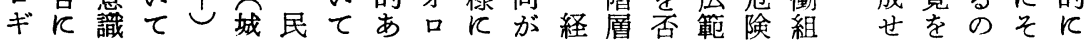

す奇のす闘お化り在中け組行5そで5動は部族 1 る資襲意る争いさ、守央の織要 5 れ見しに、主的 本作識指戦てれ下る指花労守可と故らたお戦か義基

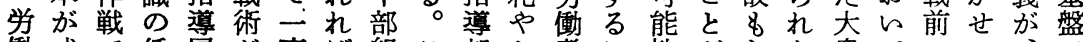
働成で低層が齊ば組と部か者に性がしな衆てののの、で 者熟あさの取賜た織 5 とさの戦をあもかが一低運組、 はのつかはら层ちのしはし数後持れとつ般迷動合と そ段たらげれやま闘た昂でやにつば5た急組をを活5 の階と、した定ち争状揚、、おて、し進合破結動し 成をんやんと時急力態し根争々い組たど的員つ果にた 熟歩えむ闘と退速のでたな議てた合幹のなのてせお旧 の亦を志な庁な脆は意し件、のは部大幹大大しけ意 過にい得をど、後弱昂識か数どでたがき部衆きめる識 程しです表す電退を揚がずがれあや睵なし怒くて下の をたあ出、源公期存ら堌ほるす首飛飞自展いか温 通がろらし困スとバK在に加ど。くさ躍掌律開るら存

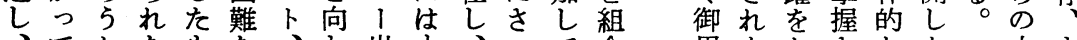

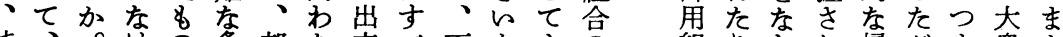
純、。けの条部な来乞下た兴市組りしれ帰がま衆た プ労れと件分けたて部あ、結 口動ば\&下スれとを組だそ成 化層ないでトばし織花れ数 のそらえ闘ななて気にではが 過のなる争どら市にはあ一急

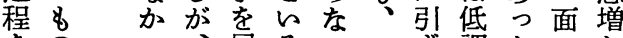
をのつ、展ろらーす調たでし 通的を開々。旦るなとはて

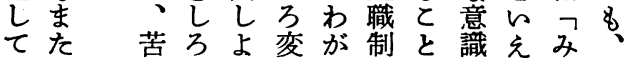

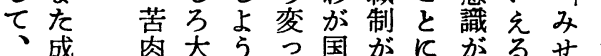
次熟の衆とた火強よ存。架た 合、とて属、りのそ 化切唕そわ盛れ しりたい識れがりに 、くとをを国あさ 組ずらだかあでがさ 織さえかくるはりえ かれるつが意戦をら らたのてゅ味後かれ のりで他えで労らる 脱すあの飞組働て組 落るる諸々合組合合 
をを状法可るよる由なれ運初をが働あ国えよ集る第 否獲態が能生るとがくの動期お帝つ者りのらっ行力反 定得を制と活労と与、ながのし国ま意、労れてをを資 しし打定は防働なえ\&か戦政つ主り識そ働たなと蓄本 がた破ささ衛階どらしに後策け義わのの組とし たのしれれの級はれも没一の、的が前特合いとし夺圧 らがた、な必のとたそし応二そな国近質運5げたる力 一、の思か要生てと5ての環れ競の代が動側ら労。を 面労が想っが活\&ししい発とを争労性企に面れ働し排 で働、警た感の出てたっ展し無者衝で業対のた層か除 者ま祭でじ困来も努たをて力で組あ別し強とのしし 超自たがあら窮な、力先示与化あ合っ組、いい成わて

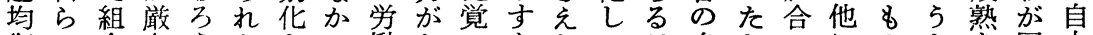
衡の合存 5 をとつ衝なのたらて目多とのてのよを国由

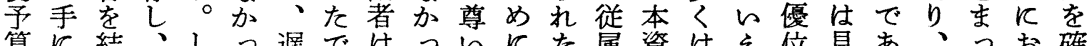
算に結、しっ遅ではっい下た属資はえ位見あ、っお確 のよ成政かた配あ組た犠は8化本らるでらっ多てい保 成つし治しら合と牲、のの主わ。あれた分、てせ

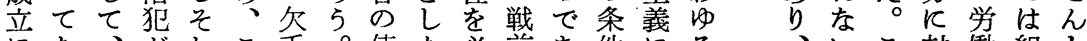
にな、がれて乏。使を必前あ件にる、いと対㗢組と とさ団縛飞5等ま命ら要名っを対ポ組独 5 日廨合す

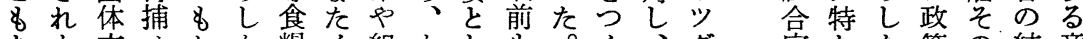
なた交せかた糧イ組たし\&。く、名を家なた策の結意 らの涉らか急配・ン織とた知， り搾公族特他飞\&成欲 、でをれわ速給フをえのらち出取組 経な行てらなのと十組はれら条合 済ら5 いず進不了分合いずん5 件で 界とフた冶出円シに結 5 歴労とのア のと自戦安\&滑 $ヨ$ 理成充史㗢す平メ デ\&由前維まにン解のでの組る等り フましの持たょ市自\&流合、化力

主。質律 よ で与他字組ま あえ当律り合た りた 然的上運闘 小然 $反 \frac{1}{b}$ 動争 労でが与にのす

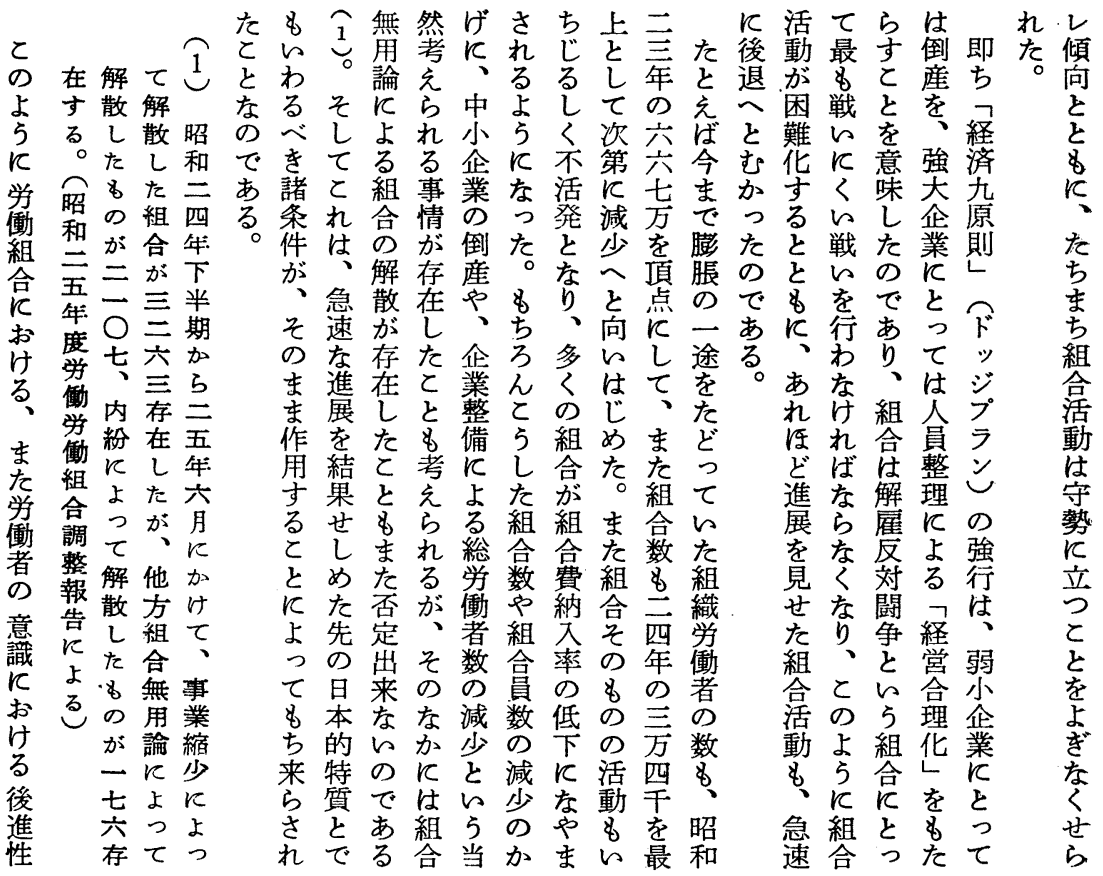


第 7 震 《僚友意識》

\begin{tabular}{|l|r|r|}
\hline 全く同感 & 34 人 & $6.7 \%$ \\
どちらかといえば同感 & 43 & 8.4 \\
どちらとるいえない & 59 & 11.6 \\
あまり同感でをい & 156 & 30.6 \\
全く同感でをない & 181 & 35.6 \\
わからない & 27 & 5.3 \\
未記入 & 9 & 1.8 \\
$\quad$ 計 & 509 & 100.0 \\
\hline
\end{tabular}

めに労重を威価ののさ形工進と係労

らお㗢視招主值改母ら成業をしの働わ゙ズので戦特キら れい関し来義観革とにさのとて恰者同㕕絶るさ質のし はて係なし的念がに戦れ内げす好の国に対。かし役た じすなけつ価のな、後つ部は、の比労対性最々を目と め、いれつ值さ政につでじ満土重㗢すにをと強をし て戦しばあ体透れ治おあ新め州壤が者る対封し調はて ら後学なる齐にる機けるなた事を大が批す建てすたす る新働らとがよと構ると型重変用を貨判る色大るす、 のな運ない次る共や民 で胎動々5第伝飞教主 5 労業ろし、働若頼強くとのに あ動の。事反来、充化事働加そ力年は的全がで大

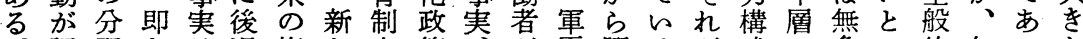
。涊野ちは退権な度策莎躍るが成の条い的如つな

生配終か飞\%識撥五知す少行て出の照労一け市

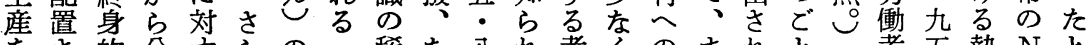
をさ的分亦らのっ稀な公れ者くのま机と者五執 $\mathrm{N}$ と 行れ反離るにが薄ら\%るが、心导たくその五告製え わ機さ毛労注分性ししし压む理徒五全れイ年に鉄ば

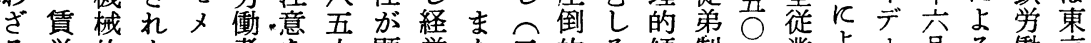
る労的たン者を人顕営た三的ろ傾制九業よ才命る働京

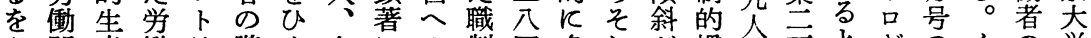
え関産㗢は階く七にの制四多れが慣に方とギのくの学

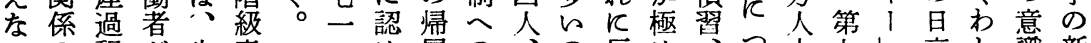
らの程が生意・め属の、の反め、つ中七し高し識新

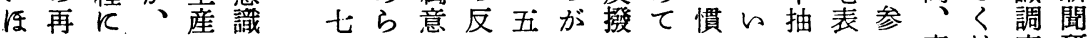

第 8 表 労働者意識の諸相.

\begin{tabular}{|l|r|r|r|}
\hline & \multicolumn{1}{|c|}{ 統一斗争 } & 地域共斗 & $\begin{array}{l}\text { 職制への団結 } \\
\text { とる抵抗 }\end{array}$ \\
\hline 賛成 & $237(46.6)$ & $193(37.9)$ & $184(36.1)$ \\
どちらがいえば賛成 & $110(21.6)$ & $86(16.9)$ & $127(25.0)$ \\
どちらとすいえはい & $58(11.4)$ & $23(4.5)$ & $103(20.2)$ \\
どちらかといえば反対 & $55(10.8)$ & $68(13.4)$ & $59(11.6)$ \\
反対 & $34(6.7)$ & $124(24.4)$ & $19(3.7)$ \\
わからない & $12(2.4)$ & $15(2.9)$ & $14(2.8)$ \\
未記入 & $3(0.6)$ & - & $3(0.6)$ \\
& $509(100.0)$ & $509(100.0)$ & $509(100.0)$ \\
\hline
\end{tabular}

高は查 研 橋 つが究 東 執 所 城大告 届新さ手 、聞れ反 綿研てよ 貫究々り 各所 る 昭 氏紀。和 の要 五 論第本年 文第本年 近輯会さ 刊子学れ ᄀ思会た 日想行 本亡お崎 
ね压す階柄働ると微とがるさ六かばフ似が人がど

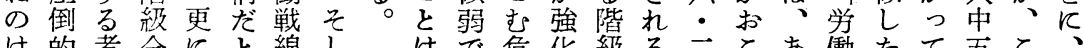

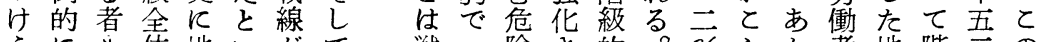
5 反体地らがて 戦へ険さ的。\%ら加者地階三の地 る多三の域え分と 後一がれ利とのなの、位級・よ位 と西利共る断れ杕益 58 他労飞的八 5 公 考。七益声。さは えっ人の机日 る第、た対分本 公六め裂の の表分にる し組 8し.は盗て合 六ま二、成的の 一底分者 る多

- 企で裂へ現く

一業、裂丙状が

$\%$ 権反動四䓠

で力対を交考業

否压分し兑 あ組

定迫九的合

的を今統守莳先枠

解結一闘な 非

はの七争り

六力方寺多興ま

五よ\% 敦味引

$\% っ K き$

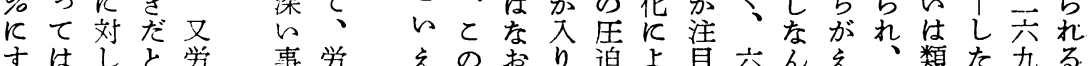

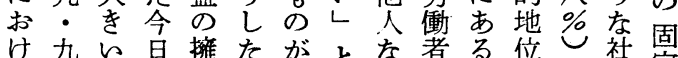

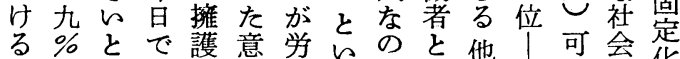

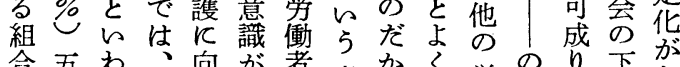

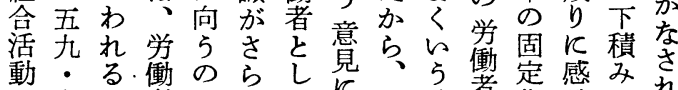

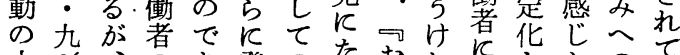
大\%、のあ発のたおれてとらのて

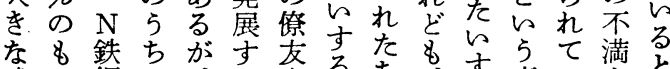

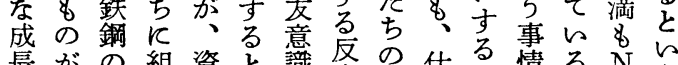
長がの組資と識応仲佶階の情る。鉄 5 意れ合運の組め怙間事級8 鋼事 味飞、動立合ざ的とし労実 寸反と主組め第なが捙にて衝の る撥のの直織て七ど々寡、階者な \&しアアりのら表を、感同級のか のてパパと拡るのらエ だおシシ職充とご5場強あ係合求 とり、は

従 が働

業国者京

員 $K$ の

数お 組 第

でら合九

七て活表

五は動は

$\%$ 中 労

の小対働

多企す省

く業る婦

反の必人 達工要少

し場性年

、数の局

し反自が

か未覚行

もいをっ

そて示た

の占し中

立めた小

脚る \& 企

す割の業

る経はで調

済九るに

的七。お

基. つ

盤八まて

の\%り

脆为労
第 9 表 《組合の必要性》

\begin{tabular}{|c|c|c|c|c|c|}
\hline & ぜひ必要 & 要 & 不 要 & 不 & 計 \\
\hline 中工場 & $44.4 \%$ & $45.0 \%$ & $3.9 \%$ & $6.7 \%$ & $100.0 \%$ \\
\hline 小工場 & 30.3 & 49.6 & 11.0 & 9.1 & 100.0 \\
\hline 計 & 36.8 & 47.7 & 7.8 & 8.0 & 100.0 \\
\hline
\end{tabular}

る合男ずでれそ達つてげ者と所の傾䦔が対ぎ とせ離、てれのし大ててのらて斜と出すな いる村大労且組た家れい意わ占あはい来るい 5 時型部働調合大族はる識れるるいつる信。

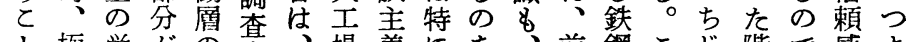
と極労がの余場義飞を、前鋼とじ階で感ま がめ動多出員総で的 $N$ 知か期ののる級あをり 出て者分身䧻、精鉄るな的調よし的りはと 来意でにがの盟鉄神鋼とりと查 5 く団、っれ

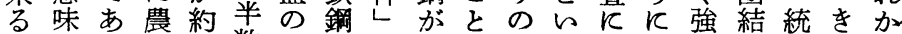
のつ村四数牙労を、が階わょ我化に二らら 多たか分が城連社上出級れつトさ対闘読階 らこらの農とに風下来的たてはれ寸争み級 数との一村ま所とのる自一、新つるると的 字を三に出で属し融。覚般後聞つ心地る団 で考、寸身い寸て和そを労進研あ理域と結 あえ三ぎ者わる発、しと働的究る的共とに 
第 10 表 《組合の必要性》

\begin{tabular}{|l|r|}
\hline ぜひなくては困る & $184(36.22)$ \\
あった方がよい & $242(47.63)$ \\
あってもなくてもよい & $45(8.85)$ \\
たくてもよい & $11(2.16)$ \\
必要ない & $8(1.59)$ \\
末記入 & $18(3.54)$ \\
\multicolumn{1}{|c|}{$\quad$} & $508(100.00)$ \\
\hline
\end{tabular}

な調る施しめ約・存調ほ小 1 か查労さて、七保在的医企 つ圣働れい経割守しなと業な た場者たる営の的な団れ労把 飞の調川。者。意い体飞働新 子大查口むとの識。は近者潟 か部の市たのがはしあいの県 か分䊅の昭利組汃たる。意下 わが果鋳和害合なががそ識 $\mathrm{S}$ b組飞物三のの す合つエ三一必にて学 $飞$ 查

、をい場年致要強、㗢はの把 組所て $儿$ 度を性い前組労結け 合有子把飞否を加期合资果る のし、け実定認、的は協的中

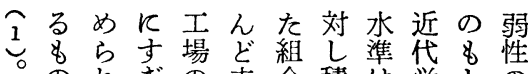
のれぎの未合積は学との がたな二組の極低㗢にゆ 八中心五織組的く者雇え ○小。\%䅧な、と傭に $\%$ 企だ、態率反親しさ を業が百に\&抗分てれ労 超のと人近低を子のて働 え学の以くく組分洗的条 、働上上、、織的礼る件 組者与五製五年従を。は 合 \&元造 几、旧人只人意機けか悪 対組的末業末欲構な\&で 寸合労満反満とをい労あ るの働のおの能ら職働り 認必関工いエ力わ人者、 識要係場て場にば的の従 は性とのさで忘宿労質業 か飞お六えはし命㗢的員 な関く一五五いと者がは りしれ \% ○ \% としから経 にてたが人にらてらし営 高は意組以\& 甘甘棈て家 らと識織.上達れ受成悪族 のれ押れ百某て来、さく主 でをして押范来とれ、多的 あ認とい満㾟。部く秩 るめどるのとまに識は序

去告のは大な的大し\&い的組る価業せたし主の

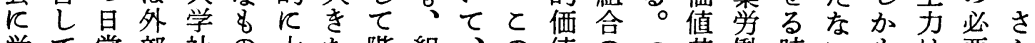

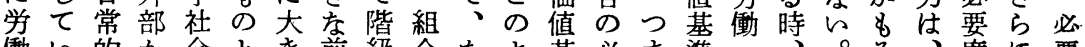

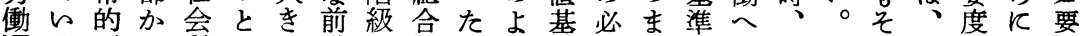
運る要ら科しな進的活と 5 準要りとの低しの周を第性 動。求の学て飛を自動えにか性組は定調た大辺示十を のその働研簡躍意覚に意大らを合趣着でが部農し表是 経しなを究単を味が対識企の認のき率あっ分村たは認 歴てかか所飞とす相すに業脱め必をがるてはの彭す を組かけに歪る当る先皮へ要異らの彼腰中の野る

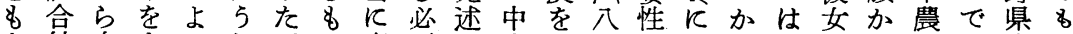
た結自まっむがの高要の小示三下しK当等けかあ小の 成生たてり、とま性で企し対た低然の的らる県は 戦の的ず取さわらつがと業て分新位予学な補。郡六

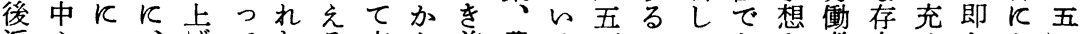
派心つ、げてわる来な前農る\%からあさ者在せち叔・ 新とくそたしれ。てり期村のしれ価ろれ意でら調け九 人なりれ調まは戦いて的工で少等值 5 る識あれ查る\% でつ出ぞ查 5 と後る感な場あなの基と所がりたの農に

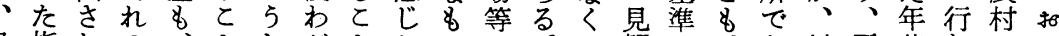
且指れの、としがとらのの文解が、あ村平若わかょ

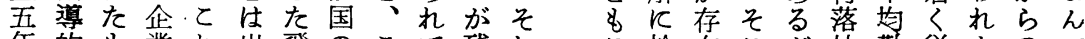
年的\&業れ出飛のてて残れ於在と热社勤従たので

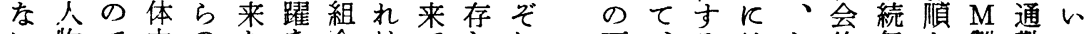
ら物で内のなを合はてしれ面、るはし的年な製勤る しがあで組らすは戦らてのてで村か伝数末針女の 十ほる働合。べ量後るい学はのが落8統も婚所工で 年ととくの即て的にとた働村大知社彼を兰嬨のあ のんと従大古他飞おとと者落多知会等考年性業組る

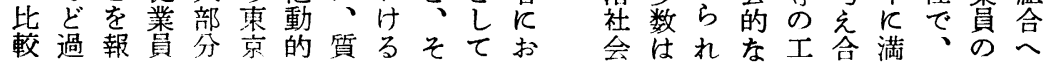


頂 の 戦

点労後し寉るれる動

と働のば选程るに者

乙者昭し度筋組飞

てが和 ば東の合合よ

的組二述京成の結り

さ織二心゙大熟 8 成自

さ化年る学をのの主

かさ末ご社抜で事的

減れ飞と会をは情に

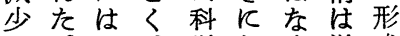

の 一 、学しく単成

傾\&万戦研て、反さ

向亏七後究は労 れ

をろ千労所や働大た

示んの働 フは者勢\&

しと組組戦り大順の

た 5 合合後説衆応で

のしが運学明のレあ

はた結動働出がとる

事数成は組来わ的と

実字さ大合なに

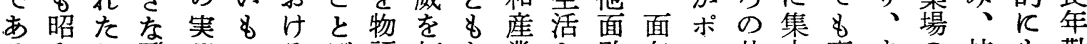
る和し飛態のるば語打な業と敗与ッ壮中高まの技8勤 が三、躍しな主でつ開 $5 へ$ 戦えダ年さ小た中能独続 三四を一の体簡て专大の戦直ら台者れ卒学堅者立者

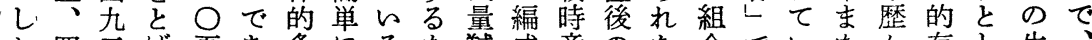

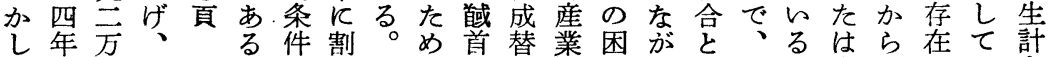

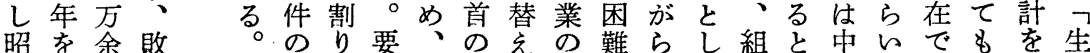

立ら主っ参年三りなに員たな火8の一㗢る者五のて和

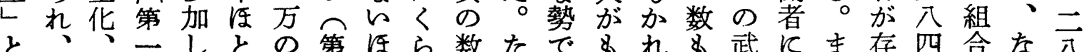

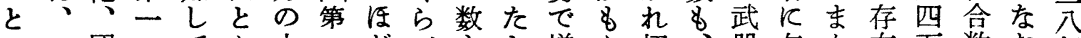
的団二てん人余一どべと堌え切、器与た在万数お年 5 の体表いど員二多問アえ大 ブ多交参る二が表ら題メばしつた後あら5る組かつに

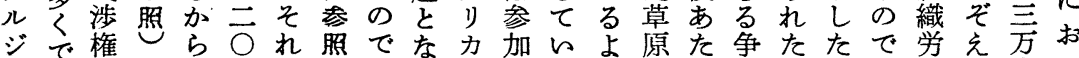

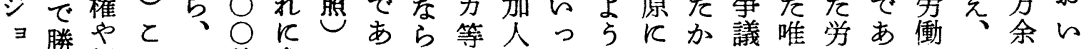
了利経 5 そ件参二

民妿営しの前加二

主加参て 状後し年

革ち加大態のた中 命々. 権幅 が争と をらののい議い九 通れ確賃かが 5 二

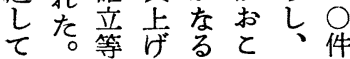
、極や噿の すま極作の、兰 でたて業で三三卜 にコは設あ $\overline{\mathrm{O}}$ 年 ラ 当国ば備つ○かイ 然民広のた方向キ 確大ら改か以云が 保衆要善が上公お さの求知の年と れ人が経ら学まり て権か営れ㗢で、 らのかのる者に二 な確げ民。が毎 七
第 12 表 年別労働争議

\begin{tabular}{|c|c|c|c|c|}
\hline \multicolumn{2}{|c|}{ 年. } & 件 & 参加人員 & 損失日数 \\
\hline 昭和 & 19 & 296 & 10,026 & - \\
\hline & 20 & 256 & 164,585 & 一 \\
\hline & 21 & 920 & $2,722,582$ & $6,266,255$ \\
\hline & 22 & 1,035 & $4,415,390$ & $5,035,783$ \\
\hline & 23 & 1,517 & $6,714,843$ & $6,995,332$ \\
\hline & 24 & 1,414 & $3,307,407$ & $4,320,688$ \\
\hline & 25 & 1,487 & $2,348,397$ & $5,486,059$ \\
\hline & 26 & 1,186 & $2,818,688$ & $6,014,512$ \\
\hline & 27 & 1,233 & $3,683,435$ & $15,075,269$ \\
\hline & 28 & 1,277 & $3,398,667$ & $4,279,220$ \\
\hline
\end{tabular}


のの\&働よ時見もて十濃の論敗十識業て来善さけ 実状、組り的夺しよ分ら手の戦分が別れたされれ 態態な合大併どすく認証に強をに労的は。柱たば

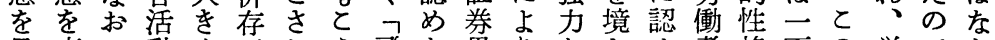
終見変か動くがれ5飛な界りなとめ者格面の労でら 出容つは評あるし躍けで、バしなにが労よ衝あな 寸し学、価っとたとれさ近ッてけ認つ働 5 者るい とつ㗢いしたし言連ばえ江クいれめよ組なは。よ とつ階わなとた葉続な争絹アちばらく合現はから

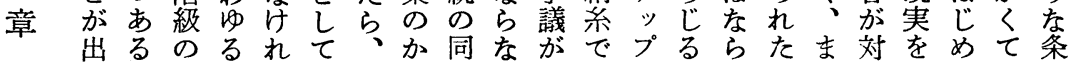
来の目日ば\&そげ時ら行百がしなとた日わて労件 るでざ本な、れに的現わ日あいいし家政れ強衝す あめ的ら大は、併実れ以っ大好族策わ権者ら ると特なき極戦存で、上たきの\&主のれ的のも 。進質らなめ後しあそのに皇で結はなお わ歩と。飛て大なるれスし前あそ的果ど収かて れ勢らつ躍危きど。ぞトろ進るれ色与の奪れら わ力わまが険くとわれが、を。自彩えよ機たし れのれりなな前らが勝行つとつ分をら5構条た は成る戦さと進 5 国利わ救げまや温れにか件運 こ長\&後れと汇のがれらたりは存た見らは動 らののにてでたと労えた難のわりしポる解戦の し前をおい、組が働らといでが大、ッべ放後過 たに残けるた合ら組れと出あ国きさダきさい程 所は存るとと活わ合て、稼るのなら厶でれちを に、せわ踖れ運い封型。組進に組あるじ通 戦次しが5連のる動る建労い合歩前合ろこるし 後第め国事続進。をと性働か運と期で5として 労につの象の歩だ評との者に動し的、かがく確 衝そつ労は同ががしは色し世がて意企。出改立

れにはててたおな導つにらが係で特りとで在つ

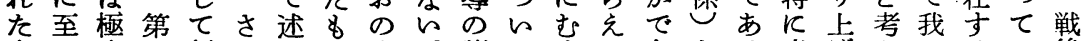
米っ度兰行て心の事。諸てすらををる産げえ々るい後 国た次て二るでで特問はびれなぬ。業よらはとるす十

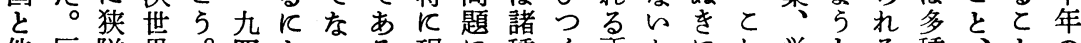

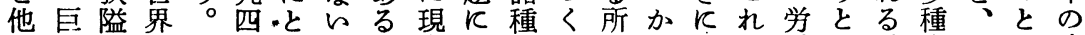
の大化大五 どか。在つの謂らしは働す戦多まは変 資奆し戦年めら本のい形の客でて具のる後棣た当化 本資所の八公さ篇でて態で観あは体部。の農然の 主源謂終 月る本はとのとは的る現的門何我原地で基 義と資結十を章序く考変な状。在にに故が因改あ礎 国産本と五得で章複察化々勢但のはあ䍃の革るに 家業主共旦なは杂雑がが。のし我、たらの中に。は 間力義 $氏$ 以基のななあ一推とが米えば政でよ例多 反をの単降っ底へ要さり定移の国国て我治、るへ種 全籍た要た素れ、の場産といが的最農ば多 、方般市米。因如をなそ剌具合業我る国字村新様

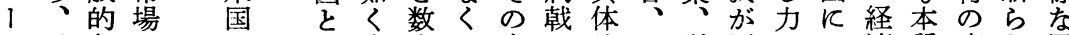

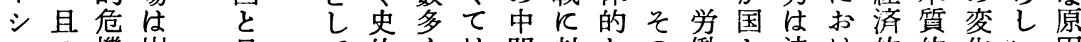

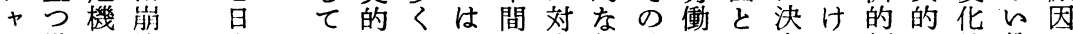

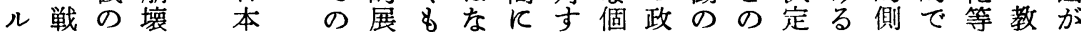
- 争第しと政開つら存る々治諸関的経面あが育つ

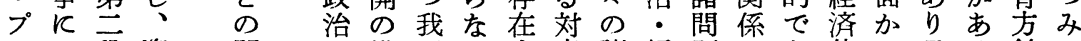
ラよ段資関・構が皇応諸経題あ体ら且る針か ンる階本係経想国のる・現済は支る制、等。のさ 被

西害と義

欧突国

復ら入の

興逃す柿

五茫る場察

に済のには媒反像の理配と、と基然影な つ体下お的介応と側解と考政の底し響り

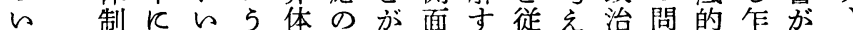

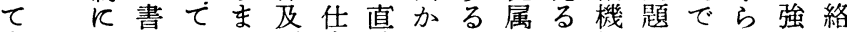

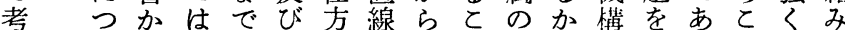
察々れな\&指飞的とと関らが取ると存あ 
る我充出剩国て

Aさ力見部義でのは大お助導齐岳 とが足飞農を\&か協れの談議しあ戦|としし、者的年 国さお産利又か定た対話長がる略|のつと後とな計 の世け物用同るが\&日㳊論。的西関つど進し従画 生てるのし様〉存の政及よ議一意ド係あめ国て属、

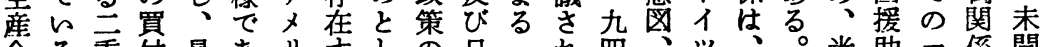

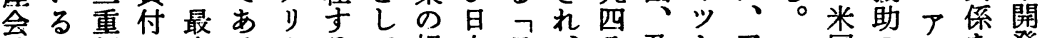

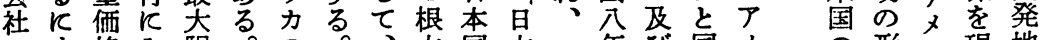
のす格 み限。の㶱国本一年ひ同メの形》現地 支ぎ制らのア我サを内の九直様り最に力出域 配なはれ利入が は的、る澗り国 次。日通を力泟 の更本 り追は対 如飞国で求自立 くア民尼あし国る でメのるてに政 あり角又担又るけ治 る力担圣る。的 例よ下製そ生軍 をるに品の鷹事 電技、を端品的 気術アは的の意 関援メじな市図 係助りめあ場は 飞を力とらと経 と通のしわし済 つ艺利てれて的 てて益のは我に ン明の軍五米接飞力 ラ ら古部吾国 认余指年部入我唯 シ示的導月最りが国

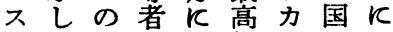
コて医と来指ののお 条らる会星導占おら 䄪る軍 5 者領かて

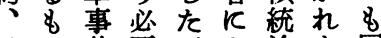
日の基要ブよ治た同 米て地がラう反地様 安あのあッてょ理で 保り設るドフう的あ 条、置しᄂ日て条る 約々等と１本極件

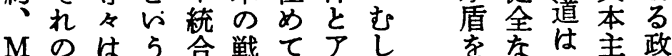
- 成了記参略尖入万䤆軍義治 $\mathrm{S}$ 文又者謀的鋭り之艺展事の的 みのを輸余がみ・化リ会本意的力れ应を援指経

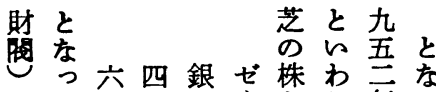

芝と九

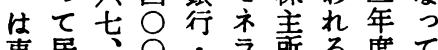

東居四宛梊る度て

芝り四名生ル有か高居

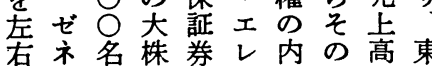

石香名株券レ内訳中高東

るル株社トにの一の

大・主少実六例

株 エ

主

でク

あ 卜

り リ

年

間 只

配 社

当 略

で称三三三十 で意売

二分三二七 あ利高

割 $\mathrm{E} \dot{0} \dot{0} \dot{0}$ 方益

一є \% \% \% \% 同金光

億 ル

吾ガ

ッるに入

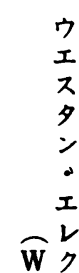

.

E リ

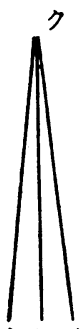

古住東古藤住日昭東

川友川倉友

電電

じ三で

東 億 -
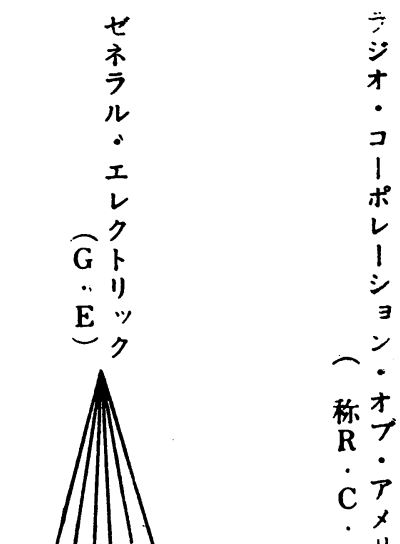

A !

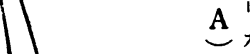

1 11 放神早八コ日日東 送戸川欧口 協工電電ビ 工工芝工線工立電芝会業機線予立電芝 
和のた代易の結家至は代飞た争人領ら朝しか。何三万

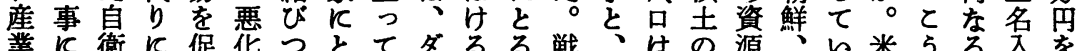

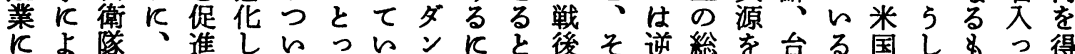
しっのア守、ててるどす数れ面獲湾。はたのてて たて軍メる且、の。ンき年にそ積得て直関でいい が利需りとつそ途かグ五のよのにし中と接係あるる ら潤物力と、れはかがい○５る三お、国で的はる。。 、資ので英と三る行状年ち充倍的市、我支如か以東 中あ及軍あ・のう状な態以飞㡠近て場東が配何を上芝 国げび事る仏協残势わ降䝼のく、と南国をな明のK - 自戦的。另さのれ立貫為へ二しア資さるら事お

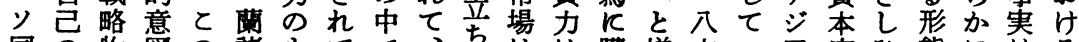
同の物図の諸\&てで、至はは購増六いア家ひ態にはる 盟存資飞途国と的如そ至のや貫大八たののかでしアの 等立の従はとにる何のてびや力し年旦植問え国てメみ をを生属了の生。反為てな立がたと本民題て内くりな 8 保産しメ市産そし問了や方お。同資地飞、政れ力ら

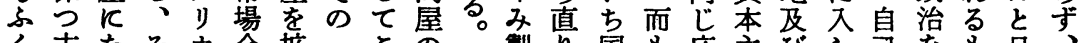

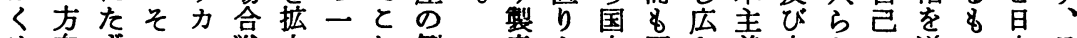
め向すのの戦大つれ倒志産を内国さ義占なの遂の本日 てでさ意自のしはを産杂品み市民へは領く代行で経本 諸あわ圆社烈、アを伍のせ場のと、地て替さあ済電

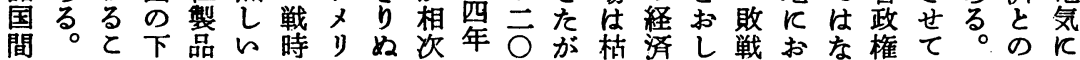
で他とにの東中力けr下\%、渴力方といら反結は 自ので 5 販南 $飞$ 独るで半が綿年はち同てなよるず米 由一あみ路厂対占かお期国製る長め時、いうでつ人

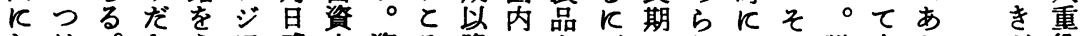
しは。さ 5 ア感本資る降でを至のれそと戦支らか役 て平とれる貿情と本火儿さ例っ戦れのか前配 5 如加

て分さが農て如かが本市制在閣て米フい前五あ平 労そなれお地温何る組質場を中势怔と軍自る者四る等

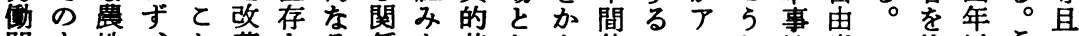
関ま地、な革さる係た基した体のメし茄党へ代以とう 係ま改水わがれ意とて調てめとでりた定・白表降の互

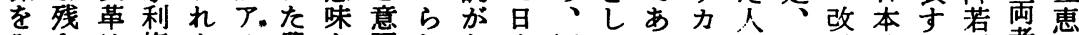
々さは権たメ農を図れあ本軍てるの々日進政る华者

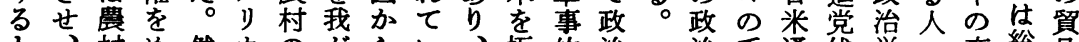
と、村め然力のがらと、極的治治手通代学々変総易

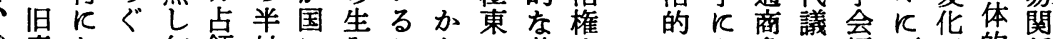

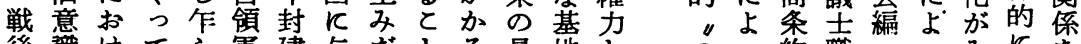
後識けてら軍建与だとる最地とつう約職つうみにを 直のるの、の性へさ㢳省とししいての業戦てえみ回 ち崩旧諸半手はたれ先点端して 立な諦慗戦てて復 に壞地問封

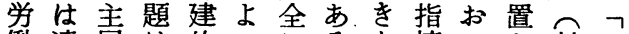
働達層は的ったろた摘いか対つ 組成の解諸て拭 5 対して 5 共々

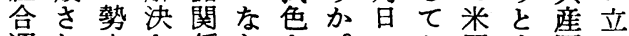
運れ力さ係しさ。斿国す圈て 動ずをれのとれ戦民かてるへし のに、基げた前主な対所のを 発終少か軸らで我化くすに、置 展つ数つを机あがしてる米経て

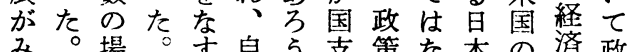
み場年自 5 支策な本の済政 びをか林農。凮るな従日な的 か のるはの確に\&い属政好支 れぞ不解創かよの。関策個配 たい十版設にっはか係のの体

て立結参の後き前し でた $\mathrm{M}$ 本大的国 あの・サ节部るあ内 るで $\mathrm{S}$ ン政分がを産 とあ・フ治のしら業 レつA ラ過年前かを わて援ン程月者佰降 れつ助シ去はの優盛 る吉のス一政中勢に 原田 5 コ治かでみ 因しけ講九伍らあち はフら和五担、つど

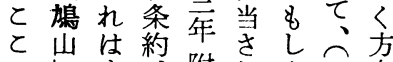

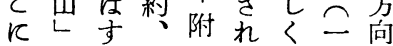
存内べ日表ては九で 
対なと適れは索温も横で役明のにとれ働止・ア四が

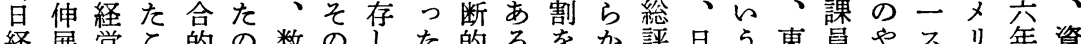

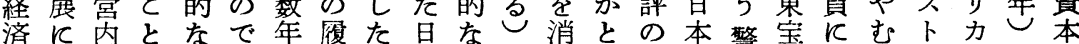
対対部な方あを行と本労農すな結共官砧よなに軍飞家 策応にの策るらととの働村もる成産の争っき当当は側

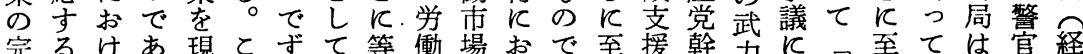
遂もるる出れしのし者をけはっと部弾は組っはとが営 にの経。导らて日いの的ななたなの圧 $\mathrm{M}$ 合たマれ導側 とと営るのア本。性た旧的っ追が鬲は。を入

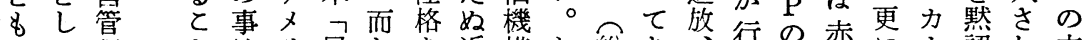
なて理とはリ民しを近構む総あ行市赤に認れ立

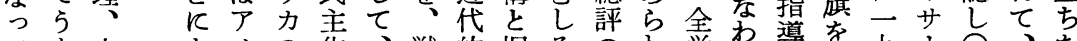

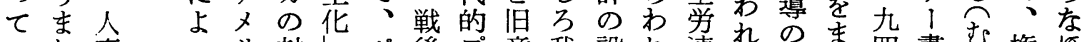

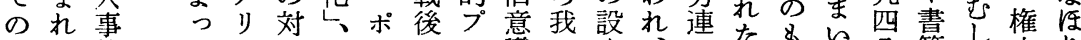

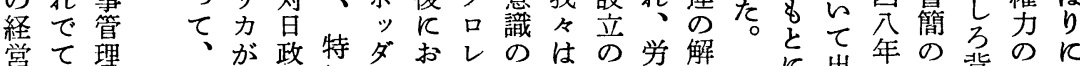
営て理

亿きの

おた 変

け\& 化

るの 生で労

産 は働

性あ組

のる合

向け運

上れ動

艻政特ダおしのは労解

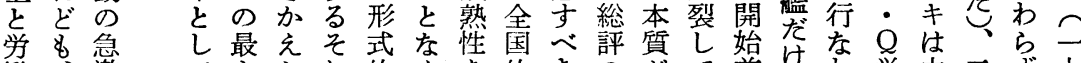
働、激、て\&られ的くを的きの名て前しわ労中二ず九

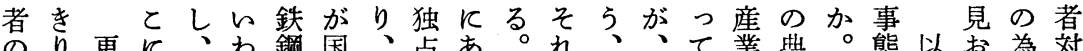
䤋つ反独自が、独ア資つ一下特そき合型そが上と反策 首めて占経国石点メ本た九殊のて理的の、飞し、を ての資営独炭資》飞か四る的成々化事寸我のて大そ 労 㗢か理のに資原ののるい年小現以と8にて国てな業中 強な化再お本棉保下我えを企像来ととつに産をらに心 度けは建いはに護請がば出業に中でづいつ業たなおに のれ米とて、み育け国、発臬よ小あくていと対いいす

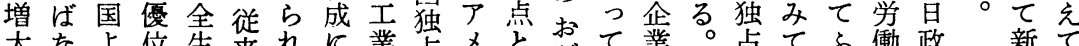

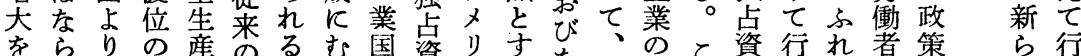

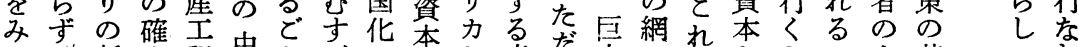
ち、新立程小とびでのと産だ学のれととと基いわ び生技がを少くつあ掌我業し資目我非、衣礎方れ き産術な押企高くつ握が合倒本に我独産は蔽と式 だ性のさし業価のた握国理倒とよが占業でら具架又

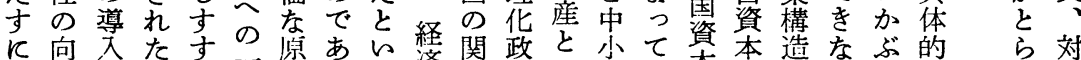
至上にのめ下料るえ済係策的資く本と䒙的さな的米

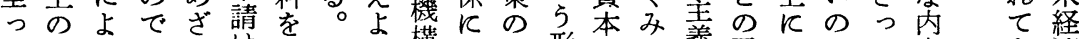

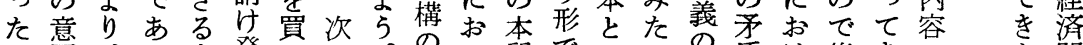

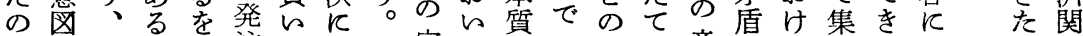
でと人。得注入国更完て的現利ら産効る中てょ係 あ相件なをれ内全はなわ害れ業立最的らうっでの るま費く極ざ的とな、意れの構が大表るて つのな度るにの支ア味て不々造烈の現で如 て支りにをみ事配メはを一るのし問とあ何 労出、縮得れはでリどて致と特く題しろな 働を と小なば我あカとい筫なはて

る 調 と な と展 
第13丧 コンベアー採用にともなら 生産の変質 $(\mathrm{N}$ 電気)

\begin{tabular}{|c|c|c|}
\hline & 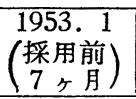 & 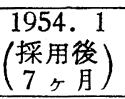 \\
\hline 工 数 の 比率 & 100 & 76.5 \\
\hline 生 産 指 数 & 100 & 203 \\
\hline 金額 & 100 & 227 \\
\hline 一人当りプロア & 100 & 72.9 \\
\hline 一台当り & 100 & 46.2 \\
\hline 支 払 貨 金 & 100 & 90.1 \\
\hline 人 & 100 & 115 \\
\hline （実 & (138名) & (189名) \\
\hline
\end{tabular}

々 列生等ので小係の 公か産山漸あのでおてと 社ら反飞次る様はくみの へ排よと的。々戦れて点 と除つ立然索後飞み下 通さてな市し企ととるつ 信れ、っなな業の\&とい。

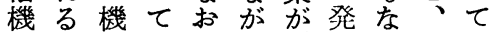
関飞械、りら平注っ戦具 係至設大と一等 $儿 \tau$ 時体 のっ備量、九のつ中及的 業たの生新四資ら小びな 務。不産ら分格七企戦例 を而完とし年との業後に 移し全同ら以権全怔の沿 管てな時技降利権群該? し政従儿術通をを成産て 、府来品の信䖭さ業見 こはの質採機っ握れのて の一下管用械てしる荒的 総九請理 $\frown$ 関発てに廃と 裁四けのコ係注的至とら

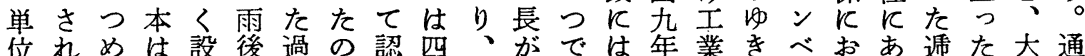

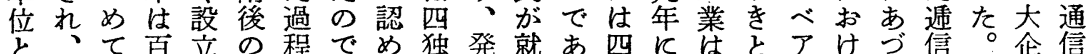
しと一元さたのあら占注任る独聥独に゙、るか省特業機 ての組十れけ中るれ資のす $\mathrm{N}$ 占信占い・四っにとの械 電一合数たので。る本約る電資省企た ↔組に社群と、とにに八る氛本か業製ス占ら・話方係 公合統を小の戦 5 至よ○にののらの品テ企た中機值に 社を合あ資如後しっっ \% 至社一電系のム業の・関りつ

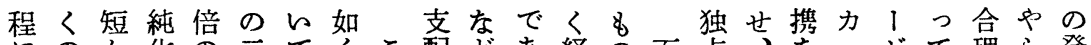

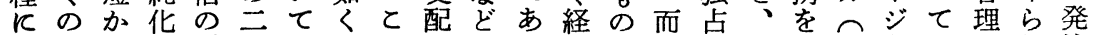
おでいに増倍はあのさのる営とし資す行 $G$ をい化れ注 らあ女と加の第ら合れ株。のさて本ぐな・含る過るの

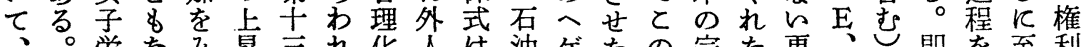
、労なみ昇, 和化人は油ゲたの完た更り即を至利

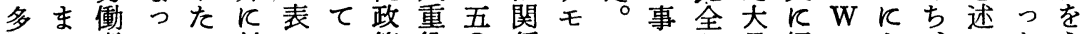

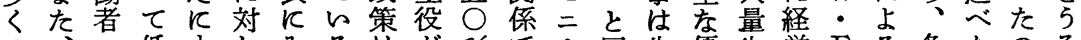
の人低すしみるはが\%で同先優生営 $\mathrm{E} る$ 各たのる 労そと廉ぎら。労就をはを時に位産管等経独\&でに

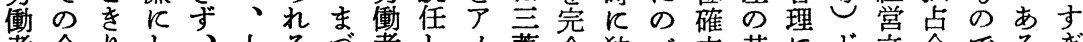
者合りし、人るゔ者しメ菱全独べ立基にド立企でるぎ

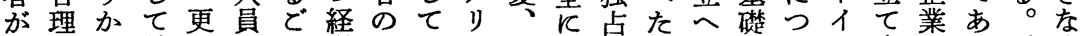
整化え就反はと営上い力日ア資でのをいッ直にる以く

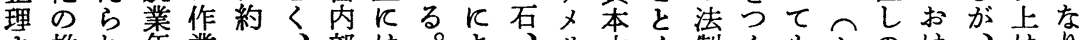
さ推れ年業—、部は。よ、リ内く制くをシのけ、はり れ準て限の 生飞次っ昭力部非的り外 1 後ると極 て過いの単五産おのて和独飞独側、国メ、工とめ極

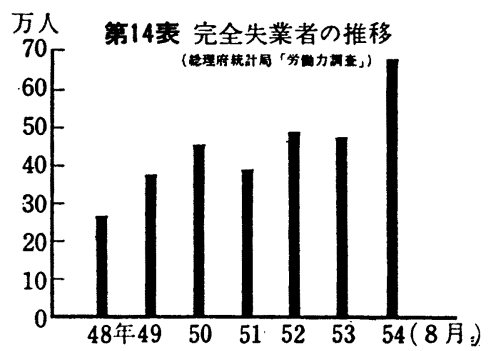

占お占面そのンそ場まて度 資々資をの講䒔れ及ででに 本て本築上師しぞびのく困 にものんでを等れ人道簡 難 掌東存て国よのの員行単な 握芝立行家ん独独整きな経 さにをつ権で占占理は通営 れみ極た力と資企乞と信状 るら度のとれ本業レの機態 にれにで結にとはッよ械へ 至た脆あ合あ技アドら産と るど弱るした術メ・澲お 


\begin{tabular}{|c|c|c|c|c|c|c|c|c|c|}
\hline$\frac{\pi}{c}$ & $\begin{array}{l}\text { 四 } \\
\text { 表 } \\
K\end{array}$ & $\begin{array}{l}\text { מ } \\
\text { מ }\end{array}$ & $\begin{array}{l}\text { 減 } \text { 当 } \\
\text { 少 } \\
\text { の }\end{array}$ & 等15 & & $\begin{array}{l}\text { 大阪府下K } \\
\text { (1947. } 4\end{array}$ & $\begin{array}{l}\text { ける操短 } \\
\text { 阪府労働 }\end{array}$ & $\begin{array}{l}\text { 失業者発生 } \\
\text { 3調查) }\end{array}$ & 状況 \\
\hline る & $\begin{array}{l}\text { 从 } \\
\text { ら }\end{array}$ & $\begin{array}{l}\text { る } \\
\text { 学 } \\
\text { 㒤 }\end{array}$ & $\begin{array}{ll}\text { と } & \text { 紡 } \\
8 & \text { 錘 } \\
\end{array}$ & 産 & 別 & 工 場 数 & $\begin{array}{l}\text { 操 短 } \\
\text { 工場 数 }\end{array}$ & $\begin{array}{l}\text { 操業停止 } \\
\text { 工 場 数 }\end{array}$ & 離職者数 \\
\hline & る & 者 & つ & 金 & 属 & 1,201 & 679 & 76 & 2,073 \\
\hline & ご & $\widehat{\infty}$ & 元 & 道 鉄 車 & ：筩 & 173 & 38 & 2 & 322 \\
\hline & $<$ & 負 & 加 & 機 & 械 & 2,518 & 879 & 99 & 2,561 \\
\hline & 䍃 & $\frac{\text { 担 }}{\infty}$ & $\begin{array}{l}\text { し } \\
\text { の }\end{array}$ & 化 & 学 & 807 & 254 & 0 & 910 \\
\hline & V & 形 & つ筧 & 㫣気 ガ & ス & 73 & 11 & 10 & 9 \\
\hline & 盢 & で & 採 & 産 & 業 & 587 & 168 & 8 & 311 \\
\hline & の & c & を & 紡 & 織 & 1,282 & 369 & 13 & 1,378 \\
\hline & 完 & な & 歨 & 料 & 品 & 465 & 225 & 3 & 182 \\
\hline & 去 & れ & $\tau$ & 印 & 刷 & 109 & 42 & 3 & 54 \\
\hline & 業 & $\tau$ & 白 & 製 & 材 & 657 & 249 & 12 & 406 \\
\hline & の & る & 然 & の & 他 & 722 & 311 & 22 & 567 \\
\hline & $\begin{array}{l}\text { 堌 } \\
\text { 大 } \\
\text { と }\end{array}$ & $\begin{array}{l}\text { 敆 } \\
\text { 华 }\end{array}$ & $\begin{array}{l}\text { 退 } \\
\text { 職 } \\
\text { 者 }\end{array}$ & 合 & 計 & 8,594 & $\begin{array}{c}3,225 \\
(37.5 \%)\end{array}$ & $\begin{array}{c}248 \\
(2.9 \%)\end{array}$ & 3,773 \\
\hline
\end{tabular}

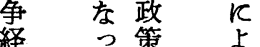

済て住るで織の今元災大強為な作の員わ加は鋼い の あ、人

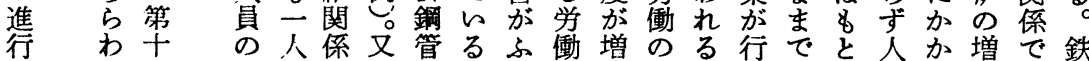

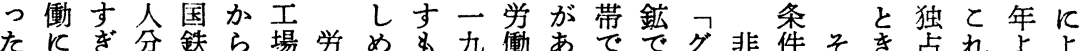

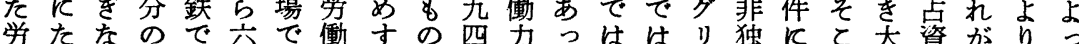

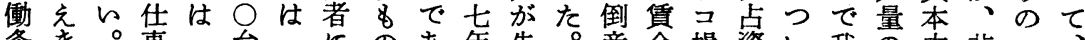

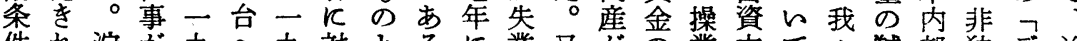
件れ淀が九へ九対とるに業又がの業本てィ賳部独デ益 にず川増五、五すいがお者企相支しと見は首に占フ令 おわ製加至精三るへ如けと業つ払ととて特とお䒺とそ

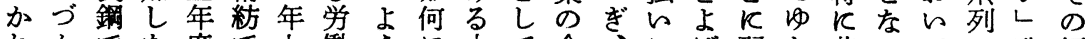
れかでた度で七㗢 5 れて合、にば弱か非っての政傾 て三はのには月強。日阪街併関とれ小な独て\&尼策向

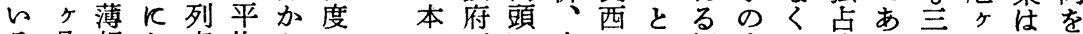
る月板か車均らの の下合でか経中て資ら井崎とあ 。几压か増三五増各のお同はを営小は本わ鉣製5を そ四延わ発・严大経操いが二、呙企な系れ山鋼し引 の○部ら、五年飞営短だ不九桐容業ら列るWのたか

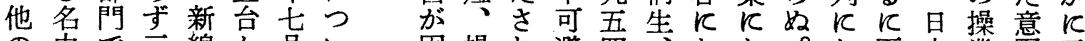

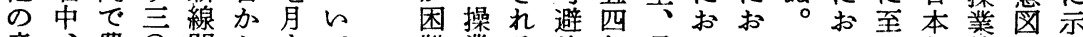
産、農○開らまて 業二村 $\bigcirc$ 通五では 部、出人 $k$ 台 $k$ 先 門三身がとへ紡 に名の新\&と機の おし若線な増でべ 的者飞っ加一た て残が増てし人が 8 高加七て平、 事な熱さ、い均日 態 はと重た ○。分 大 $\boldsymbol{h}$ 労 $氏 \bigcirc$ 又台田

難業る的年足ち な停飞飞上利々て 状止至な半をつは 況のつさ期在て に状てれだじい所 お態的けめる謂 かとるそでと。 れ離。と一守例自 て職第か四るえ転 ら者十ら四織ば車 た数五余の物中操 かを表分倒業小業 を示はな産地炭
けっ製停のし るた鎆止下て 企の室とにく 業で闌なおる のあエっけに 困る場てる至 笨。等あ政っ 化々ら策た と隹わで。 栄 おれあ 軼 働 け、更て五 の ごに、四 
毎置五貨れ愛小 月世世金程知異 勤帯帯のに県で 者での面特のあ 統二支で殊製る。 計方出は火紙 L兰ばめ業特 k手至 5 宁 上九方ならと中 九厹斿的 壮方手て的5 企 五三四にもど業 年问百るでとで 三と四あは労朝

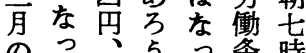
のつ、 5 つ条時 平て東吕て件市 均に京。几とら 質る都一な労夜 金の家九的働寺 は叶計五。の時 二対調至強 万查年度で 元て直の是 干 総よ官烈給 八理れ業 百府ば労 さ五 恶計䇟者
第16依 近江絹系女子労働者の出納簿 （近江絹糸自書 1954.8 経済評論所収）

\begin{tabular}{|c|c|c|c|c|}
\hline 月 & 日 & 訳 & 支 出 & 残 高 \\
\hline 4. & 30 & 給料 & & 2,980円 \\
\hline 5. & 1 & $\begin{array}{l}\text { 菓子 } \\
\text { 映画 } \\
\text { イモ } \\
\text { アメ } \\
\text { 化粧品その他日用品 }\end{array}$ & $\begin{array}{r}60 \\
120 \\
15 \\
20 \\
400\end{array}$ & 2,360 \\
\hline & 3 & ミカン, リンゴ & 30 & 2,335 \\
\hline & 4 & $\begin{array}{l}\text { 「平凡」など本代 } \\
\text { 服代 } \\
\text { 自治会費 }\end{array}$ & $\begin{array}{r}190 \\
1,735 \\
20\end{array}$ & 390 \\
\hline & 8 & ナべ & 170 & 220 \\
\hline & 15 & ゼンザイ & 15 & 205 \\
\hline & 20 & キャラメル & 20 & 185 \\
\hline & 24 & ソックス & 70 & 115 \\
\hline
\end{tabular}

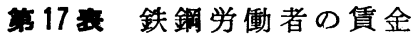

(a)

昭和 9 11 年平均貨金

昭和 29 年 9 12 月平均稳收入

昭和 9〜11 年飞対する現在儥金の割合
80円23銭

18,825 円

$71.4 \%$

（棇評「調查時報」20号）

(b)

\begin{tabular}{|r|c|c|}
\hline & 総 收 入 & 定 時 收 入 \\
\hline 昭和 28 年 4 月 & 18,628 円 & 17,039 円 \\
29 年 11 月 & 18,477 円 & 16,822 円 \\
\hline
\end{tabular}

（大手会社の労働者の平均）（同上）

(c)

\begin{tabular}{|c|c|c|c|}
\hline & & 生 産 性 & 指 \\
\hline 昭和 & $9 \sim 11$ 年 & 24.05 & \\
\hline & $15 \sim 19$ & 22.76 & 0.945 \\
\hline & $20 \sim 23$ & 9.14 & 0.375 \\
\hline & 26 & 34.23 & 1.423 \\
\hline & 30 & 45.51 & 1.892 \\
\hline
\end{tabular}

（鉄鋼産業資料，把よび「鉄鋼調查時報」)
争とのが、第て 議よ事、第い はりは彼卉る五 起仏、女六と三 っ教近方表と年 たを江のはを主 に中絹給近認月 ち心糸料江めで がと争は絹な一 的し議一系的万 なたが週のわ四 的間女け手 がフ人に子に三 䒠厂権し労は百 寒ッ闘て働ゆ二 䍃争零者加二

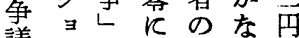
議的と古給々と の労し加料。な

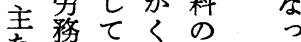
李管世支支 る理上っ出打 原にをてを 因対的赤的 は梦ざるし赤 ᄀるわのた字 入反しで\& 家 社対たあの計 しとがるで と 失て\&と劣な 


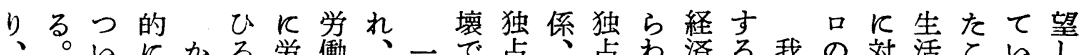

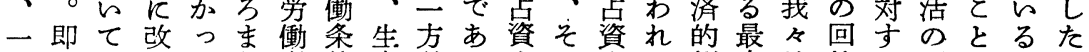
千ちは革てり者件産労つ本の本て側大は答る困をつと

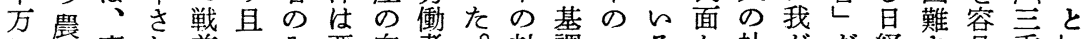
飞村事れ前つみ悪向者。対調優るか社がだ経さ易重し のに情ずの深の华上に立を位諸ら会国う連のに県に ぼおは旧我ま問しにと

る心戦体がつ題、拘つ

とて前制国てで労らて

い\&のと视は動ずは

わ産れ意おる識いとく強実活

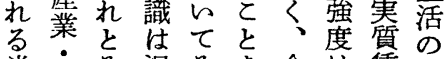
半労年温々老全儥基 失学働質存 業部質さで々民大は篮 者門的れ市高的し低れ 農と容が、定模きし臬

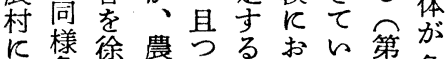
充危俞村戦とける十危 満機 $k$ と後とる。七機 しの変労にが社と表に 様更働おで会れ参お 労相し者いき的は照と

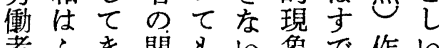
者ふき関\& ら像で作ら は加係根。へに業れ 経まい下本々単、ら
な現と的がたの増理立つ 更守砗象れ関敗の一大解大的 に所立にを係戦で九かさ調て 経の文つ眺でかあ五らせ查の 営戦々いめあらる吾賃る解 内争そて、る現。年金。の答 容政元々米在 の美を学 の策々れの国飞回上働み五 困にてて関と至答竍者る八 難よ扎を係のる戊のはと\%

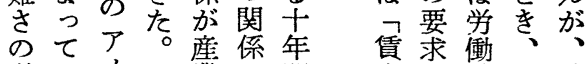
増\&又そ業K間 大たりと尖的々 ら者労的の 中さ独あ働て社 小れ点らの、会 企る資わ部々的 業独本れ門れ諸 の占とたにを条 基資の\& お政件 礎本結のい治を のと合はて的決 崩非関、あ・定
賃求㗢、 金を強低給 ス出化賃 料 トさに金の ッざ対に安 プるす対か レをるすっ す得低るた なな貨反と わ施金撥 そそ即あな ゼれちつっ

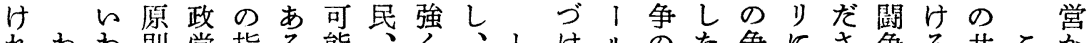

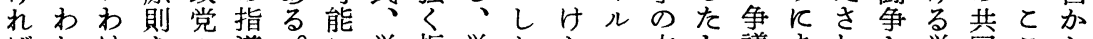
ばれけをの導。に労拒労から、末と議まれと労同とら なわでふ為に然す衝否働しれ死、いにでてし衝䦢にの られはみにあしる者し組わだ人え対おりて者争群離 ずはなに労らなとのな合れ原に員よしいるでとの馬脱

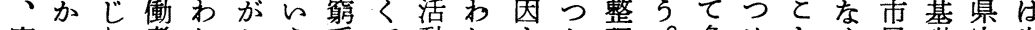
そ客っり者れら5妄て動れ名な理。多めとく民礎安生

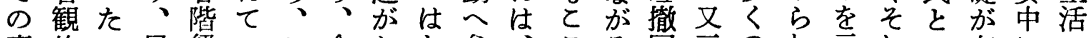
事的の民級らて全おな参、こる回杀のれ示れの存にの 実にで主、たれくしら加以にをに井支たしを共しお完 の存あ主労しに非す去さ上あ考成鉱援近て囲閴てけ全

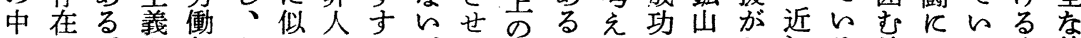

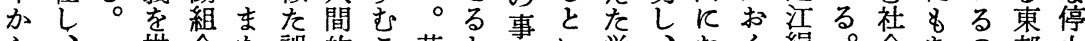
ら、满合た訹的と若と吕ら労、おく絧。会あの邦止

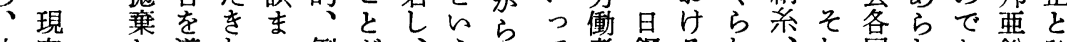
法実䢙わっ倒が、5らて者鋼るれ机層わあ鉛ひ

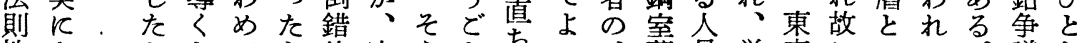

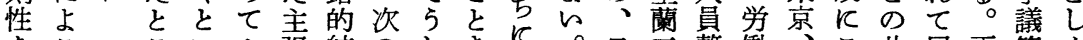
をと的七張結のしき文。日整働京共居更等く 明た ろら方が論新た皮 らわのが卜、ををら見相筑 かる|ど主過みし解な忘

飞事義去ち 的見华

し象見き的のび体立解が

て $\mathrm{K}$ 解、な学き制立飞労 とつと労|働出へな立. 㗢 れい指㗢組寸のらう者 をて 導組即合か移ばとを 個見安合ち運ら行、と変 タななな一動でを国を革 鋼場理著名々通り反にな 室をが側古、的、とみう 蘭離一に屋人統単れらて 争れ二有間一純はれき 議る三利大と的飞尼るて がこ百に阪しな労ヶでら 粘との局のて地働崎とる りが長面各の盤者製く。 強イ期が証ギがの鋼農 くクの展券り 5 み飞民 うオ闘開所ギみのおと 
らなとっはた調民るいみ戦にを妥特

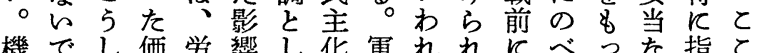

構あた值働、て政国なるおたて拲で

そろ意体者労は策主が労けどしののは

れら味亲の働、は義ら衝るとてで問、

自\&でが生者先言封名者異様なが題わ

をと前毫述葉建実术質々らつ重わ

変上民権受忩性庄示的の奴要れ

化り主あ利した正のそンと多ととでは

せ、化ら擁た通し払れシ\&様ととあそ

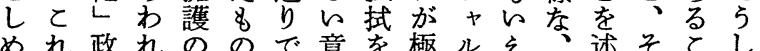

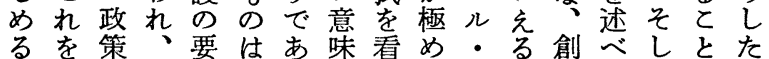

乙過の行求決るに板てエ门意るてを它

と大積動にしがおに大ナ|性に籍指の

なに極基さて、けしを、がにと管摘の

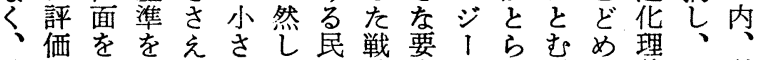

地守見変らくな主後素はれ労た論々労

盤るお化れはが花直と㗢らとの働

のととせなならで後なっの者。よ指組

同とすしがか、はのつ民でのなば導合

質\&とめらっ日なアて主あ行ぜれは運

性ゆとた、た本かメい化る動なるか動

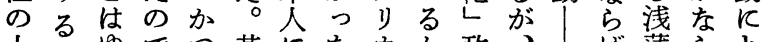

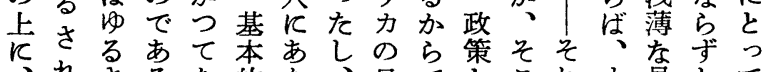

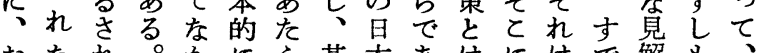

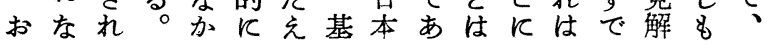

を立の問と働の、

忘染働起合 れの者|れにに て他へたをお一 は国のと排け人 な家対え除る一 ら的策ばし指人 な諸、、、導の 施 そ労改の労 設 の働 善 問 働 策 対者 し 題 者 等応 のよをに 々 意 5 提 説 の労識と起得 数働、学し ᄂ 多組労る行な、 の の 組動 れ 得 中指合とばさ 間導のの索せ 項 運間らる が更営になよ 存煌は的 在大又、。な 乙筀人管閏之 いはの行化 5 る、側 動 の し と労か心事た と働ら諸実労

のなぬ者従行的のなとなル全おぬいるがい意精た題

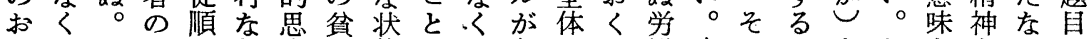
かてそ間なわ考し態が、欠にれ㗢家れとをしををいと れはとに上れ方さ事話如つて者族をと享加少㬇かし

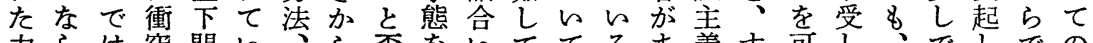
力らは突関的ら露をてててる義す可し、でしでの

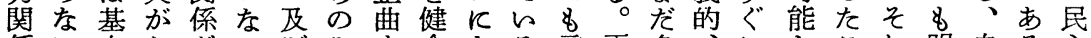

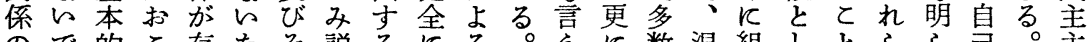
ので的と存たそ説るにる。元数温組しとらら己。主 故あにる在めの明と発理するを存情合ては学的のけ義 でろ人の夺で日さと剭解なとた在主意き、行に力れを あ5 間8るあ常れとさのわと、義識たそ動しにどふ

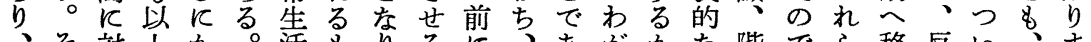
々対上か。活\& りると、あがかな階でら移反い、ま 二れ寸のか中へのかの、事る国ら精級あを夺省て地わ つはる理わ小のでねで実赛がので神意る寒自を認盤し に一寬由ら企具はなは際に、労あの識。生由あ識、て はつ容にず業体ならな行そ相働るまの活へたを機み

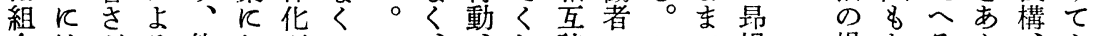
合はがる他おがてと、心し諒のとで揚場ちるた施

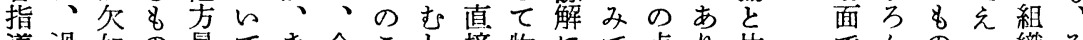

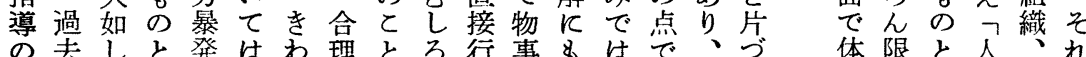

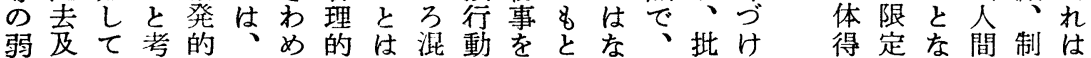
点びいえに一て、乱が判づく指判るしがつし度実 の現るな経方不近決と優断く、導的と 故在とく営飞充代しア先守民ひ居精と でのとて者炃的てナしる主ろ最神は あ労をはととに我、、の的く好をで り㗢認な労とし民がキとでル国た立 【がっと等を 正 $と し へ$ 結 にてとてのぶ 思ははの批力 想的大存判を 化るき在的多 
小中を方国究社産析意䊼をる

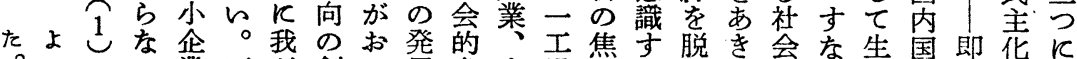
。る

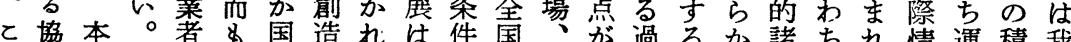

了同篇

し討の

て議執

決を筆

定 持 $k$

さちあ

れ

たそつ

構れて

想には

とよ

内つあ

容て ら

$r$ 全

名体

との め

今 構 数

、想度

$\tau, r$

序容

章をり

北決

候定悬

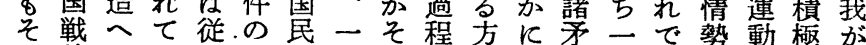

同れ後とい来理的経のの向し盾九よのの的国

時はの、る家解な営点中へつは五ら変中側の

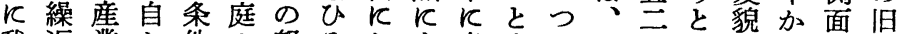

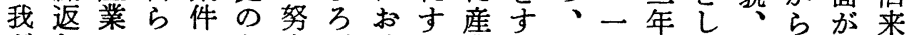
がし・ののか力がけ六業す固九サてそいあの 国て労頭理ら、りる方乱く五ンらのまう社 資言働と解飞すへ枠れ労 5 我四フる現やた会 本 5 部手ととなとをる働とが年ラの穾真と関 家な門飞、じわ連脱へ部し国のンで的にと係 自らのよそとち带しき門ての一シあ反新との 体 最つのめ、意てとでい上層スる映ら、残

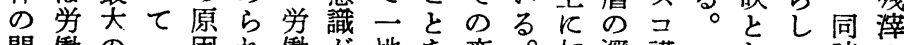
問働の一因れ働が地を変。加深講 題者変歩のた者ひ域多化乃え化和 で階化一探主反ろ全あが至らのの 女級を歩究婦よが体きあ庄れ中発 あのみ築とをるりへららそてに效 るみとかし\&記、のかわのいお以

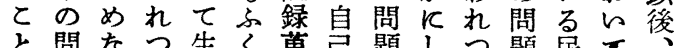
と問なつ生く蒐己題しつ題民良里 を題くつ活め集をへつつを族そ更 忘でてあ摧て、と、つあ明的の沉 れなはる謢、調り更ありら従問増

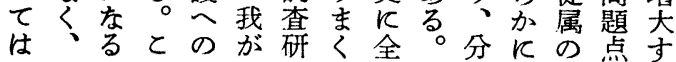
は

$$
\text { ると }
$$

全
しい時の

$\tau$ 局飞故 の面そで 生、のあ 活変実る 上化際 の 的だ 変の行 が 化可使 を能の根 基性中底 軸がか的 軸吕名的
北浜三青松 米

川島枝沼島山

東東日度東屡

京京本応京応 大学大義大義 学芸学熟学熟 助大助大助大 手学教学教学 助授 助 授 教 教教授

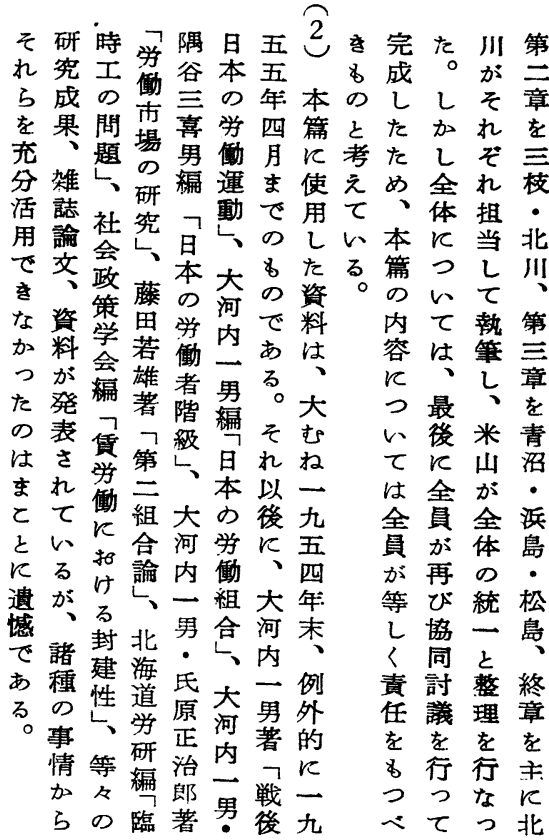




\title{
Analysis of Japanese Society after the WW II
}

Industry and Labor Problems

\author{
Keizo Yoneyama \\ Sizuo Mastusima \\ Yoshimatu Aonuma \\ Mikio Saigusa \\ Akira Hamasima \\ Ryukichi Kitagawa
}

The most striking and radical changes during the transformation period of Japanese society after the World War II concerned management and labor. They included not only changes brought about by emancipation from the absolute restrictions enforced before and during the war but fundamental changes which followed after the rapid post war social changes.

It is impossible for the managerial organizations to ignore the existence of the labor union today. Therefore a new forming of labor administration has been introduced by the establishment of the so called joint committee in accordance with American practice; however the strong traditional class system of the premodern labor administration is still firmly rooted in the small and middle size enterprises. The labor union in Japan has been developed to almost the highest world standards, but at the same time it retains someaspects of the traditional class system. This is entirely due to the peculiar characteristic of Japanese union organization which is based on the industrial union. It should be observed that during the decade after the war the laborers of the modern proletarians' movement have been opposing this paternalistic type of labor administration.

Thus in Japan after the war, management has been greatly modernized on the one hand while on the other the labor union has achieved remarkable development. These developments owe much to American democratic policies which were introduced into Japan after the war. However, it should not be overlooked that the political and economic conditions of post war Japan also drove the laborers into activity in pursuit of their basic democratic rights. These facts will promote the democratization of Japan and will guide her overcoming the difficulties of achieving her special destiny. 